\title{
Basimarols A, B, and C, Highly Oxygenated Pimarane Diterpenoids from Basilicum polystachyon.
}

Yuen P. Tan, ${ }^{\dagger}$ Yongbo Xue ${ }^{\dagger}$ Andrei I. Savchenko, ${ }^{\dagger}$ Sevan D. Houston, ${ }^{\dagger}$ Naphak Modhiran, ${ }^{\ddagger}$ Christopher McMillan, ${ }^{\dagger}$ Glen M. Boyle,,$^{\S}$ Paul V. Bernhardt, ${ }^{\dagger}$ Mark J. Walker, ${ }^{\ddagger}$ Paul R. Young, ${ }^{\dagger, \ddagger}$ Daniel Watterson ${ }^{\dagger, \ddagger}$ and Craig M. Williams ${ }^{\dagger, *}$

tSchool of Chemistry and Molecular Biosciences, Faculty of Science, University of Queensland (UQ), Brisbane, 4072, Queensland (QLD), Australia (AU).

${ }_{\ddagger}$ Australian Infectious Diseases Research Centre, School of Chemistry and Molecular Biosciences, UQ, Brisbane, 4072, QLD, AU.

§QIMR Berghofer Medical Research Institute, PO Royal Brisbane Hospital, Brisbane, 4029, QLD, $\mathrm{AU}$.

*Correspondence to: d.watterson@uq.edu.au; c.williams3@uq.edu.au. 


\section{Table of Contents}

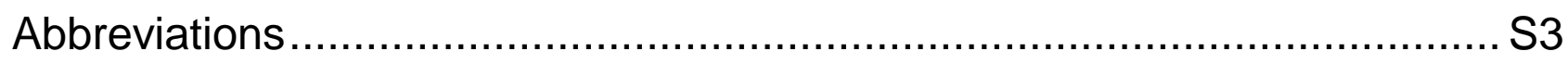

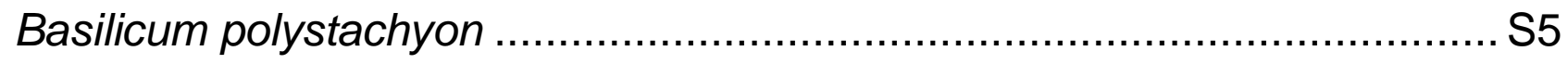

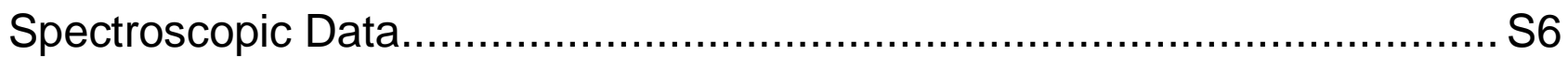

Crystallographic Data ....................................................................... 441

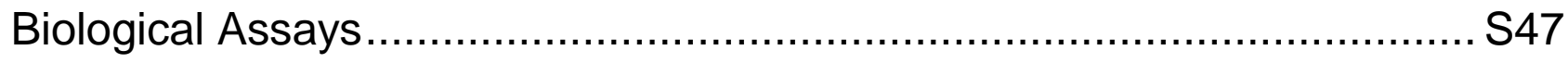

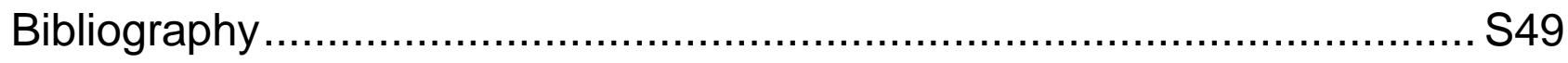




\section{Abbreviations}

\begin{tabular}{|c|c|c|c|}
\hline${ }^{\circ} \mathrm{C}$ & degrees Celsius & $\mathrm{HMBC}$ & $\begin{array}{l}\text { heteronuclear multiple bond } \\
\text { correlation }\end{array}$ \\
\hline$\Delta$ & heat/reflux & HPLC & $\begin{array}{l}\text { high-performance liquid } \\
\text { chromatography }\end{array}$ \\
\hline$\delta$ & chemical shift & HPTLC & $\begin{array}{l}\text { high-performance thin-layer } \\
\text { chromatography }\end{array}$ \\
\hline hv & photoirradiation & HRESIMS & $\begin{array}{l}\text { electrospray ionisation high- } \\
\text { resolution mass spectrometry }\end{array}$ \\
\hline${ }^{1} \mathrm{H}$ & proton isotope & HSQC & $\begin{array}{l}\text { heteronuclear single-quantum } \\
\text { correlation }\end{array}$ \\
\hline${ }^{13} \mathrm{C}$ & carbon isotope & $\mathrm{Hz}$ & Hertz \\
\hline $\begin{array}{l}\text { anti- } \\
\text { DENV }\end{array}$ & dengue virus inhibition & in vacuo & in a vacuum \\
\hline ca & circa (approximately) & in vitro & within the glass \\
\hline calcd & calculated & in vivo & within the living \\
\hline $\mathrm{CDCl}_{3}$ & deuterated chloroform & IR & infrared \\
\hline $\mathrm{CH}_{2} \mathrm{~N}_{2}$ & diazomethane & $J$ & coupling constant \\
\hline cosy & correlation spectroscopy & $\mathrm{MeOH}$ & methanol \\
\hline DBE & double bond equivalents & $\mathrm{mg}$ & milligrams \\
\hline DEPT & $\begin{array}{l}\text { distortionless enhancement by } \\
\text { polarization transfer }\end{array}$ & $\mathrm{MHz}$ & mega-Hertz \\
\hline ESI & electrospray ionisation & $\min$ & minute(s) \\
\hline et al & et alii / et aliae (and others) & $\mathrm{mL}$ & millilitre(s) \\
\hline EtOAc & ethyl acetate & $\mathrm{mmol}$ & millimole(s) \\
\hline $\mathrm{EtOH}$ & ethanol & mol & moles \\
\hline eq & equivalents & $\mathrm{mp}$ & melting point \\
\hline FGI & $\begin{array}{l}\text { functional group } \\
\text { interconversion }\end{array}$ & $m / z$ & mass to charge ratio \\
\hline$g$ & gram & NMR & nuclear magnetic resonance \\
\hline GCMS & $\begin{array}{l}\text { gas chromatography/mass } \\
\text { spectrometry }\end{array}$ & (NOE)SY & $\begin{array}{l}\text { (nuclear Overhauser effect) } \\
\text { spectroscopy }\end{array}$ \\
\hline $\mathrm{h}$ & hour(s) & NP & normal phase \\
\hline
\end{tabular}




$\begin{array}{llll}\text { ppm } & \text { parts per million } & \text { TLC } & \text { thin layer chromatography } \\ \text { PRNT } & \text { plaque-reduction neutralization } & \text { THF } & \text { tetrahydrofuran } \\ \text { RP } & \text { reverse phase } & \mathrm{v} / \mathrm{v} & \text { volume per volume } \\ \mathrm{Rt} & \text { retention time } & \mathrm{HL} & \text { microlitre } \\ \text { SNIS } & \begin{array}{l}\text { silver nitrate impregnated upon } \\ \text { silica gel } \\ \text { room temperature }\end{array} & \mathrm{UV} & \text { ultraviolet } \\ \mathrm{rt} & & & \end{array}$




\section{Basilicum polystachyon}

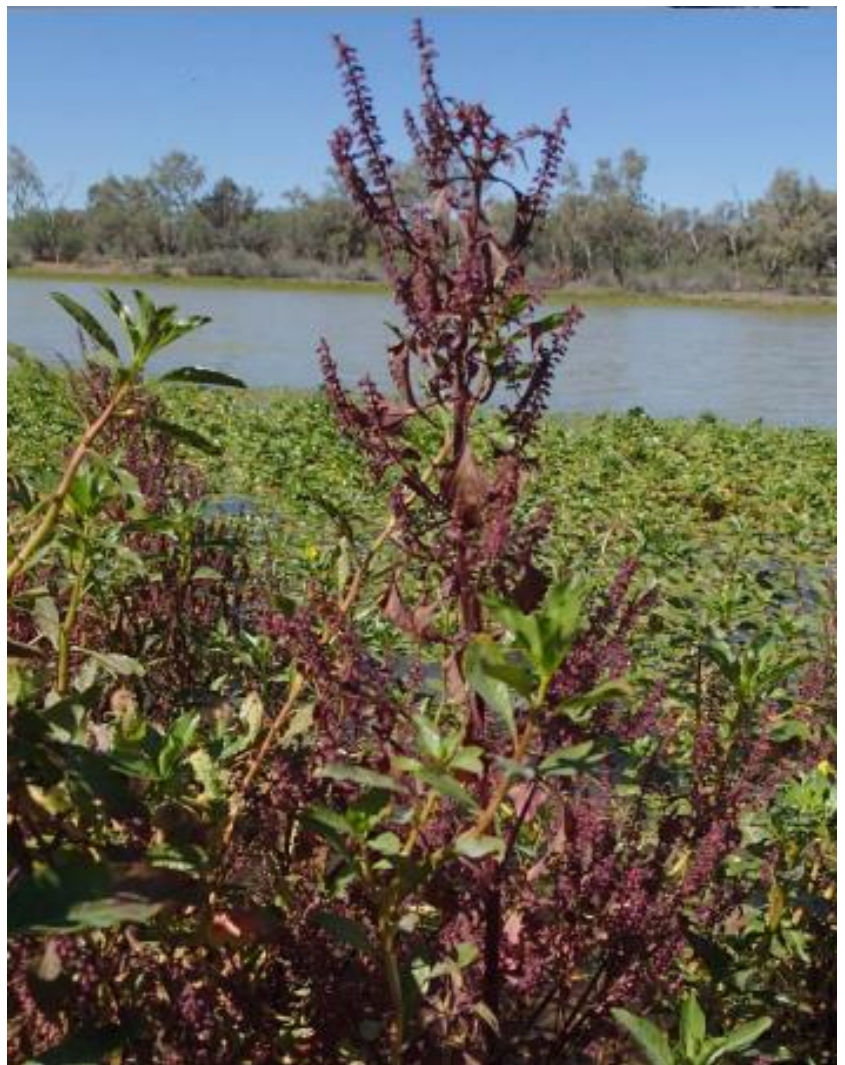

Figure S1: Basilicum polystachyon, Welford National Park (photo by Dr A. I. Savchenko). 
Spectroscopic Data 


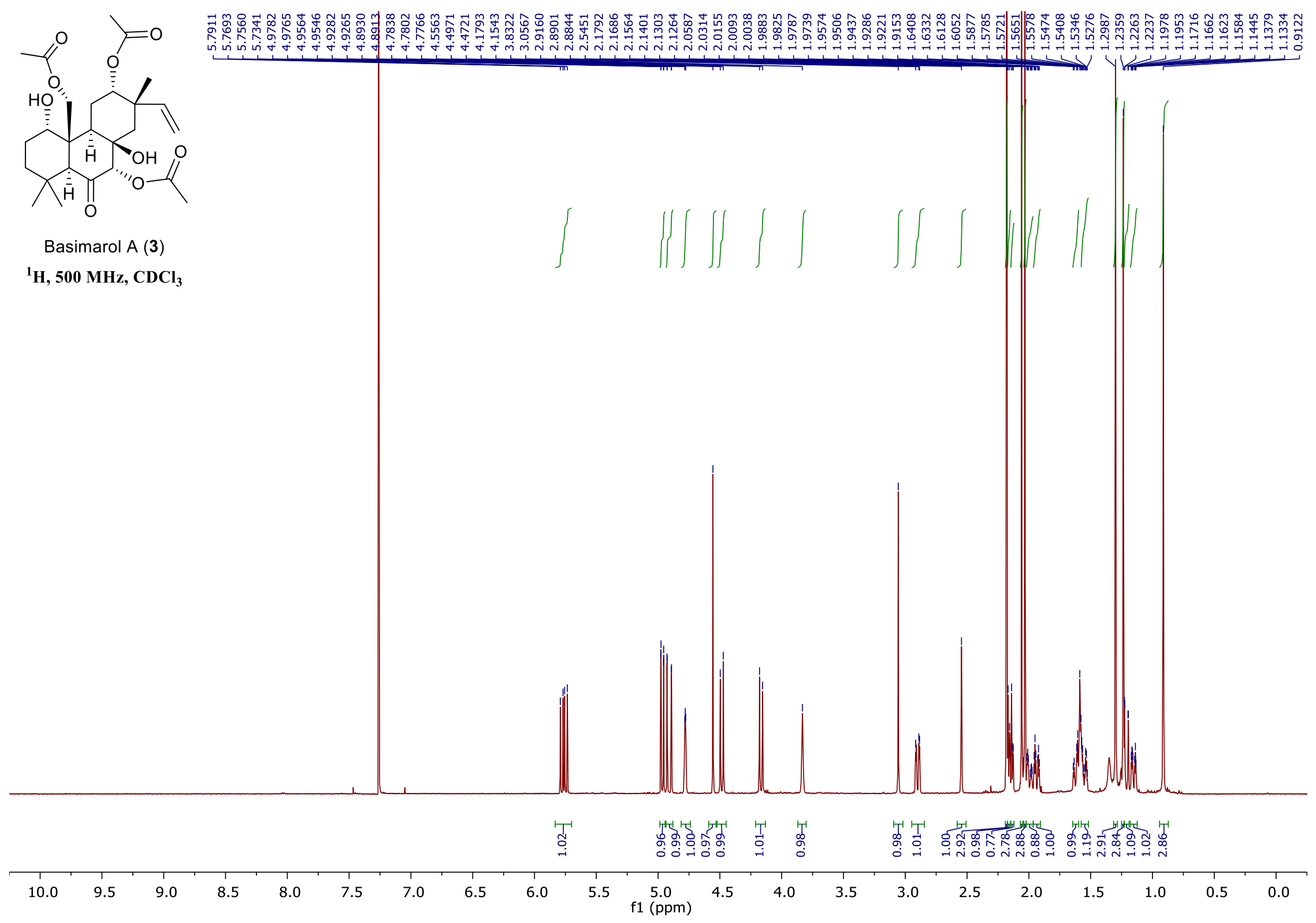




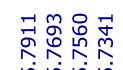

जivin

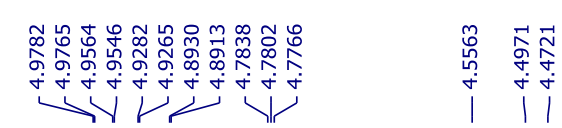

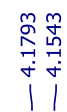

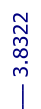

$\Im$

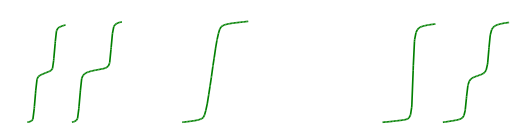

$\int$

$\int$

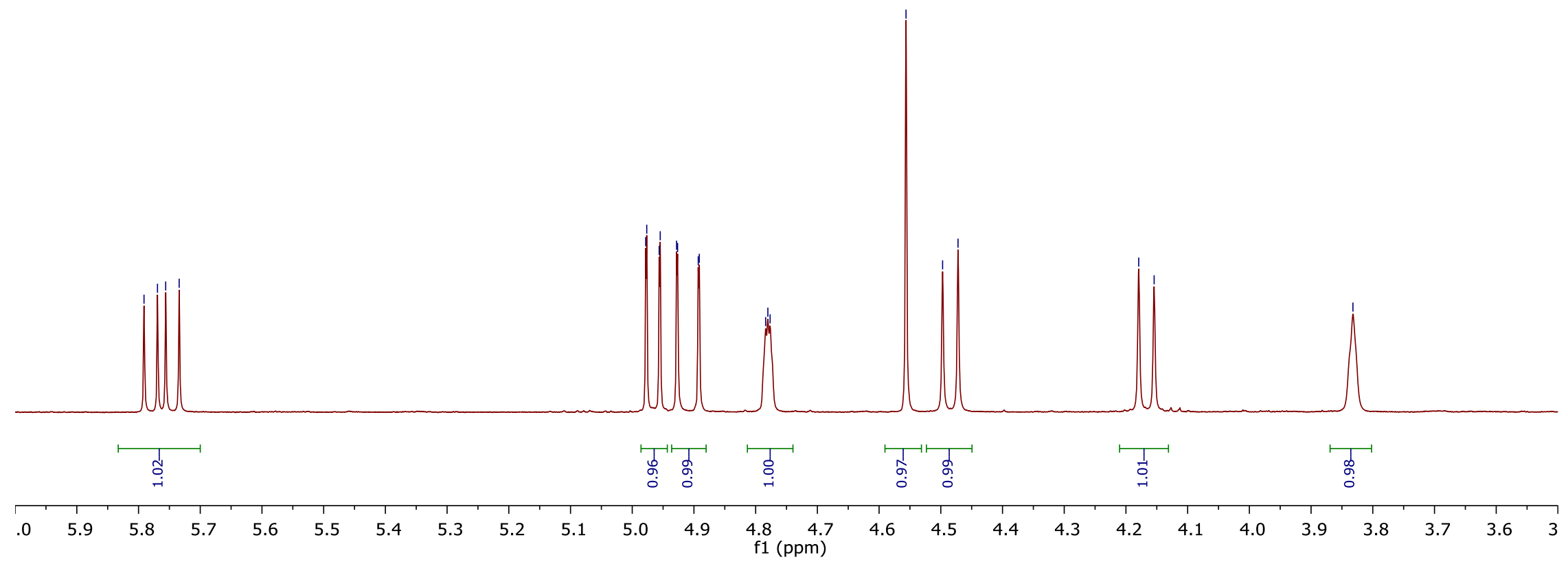




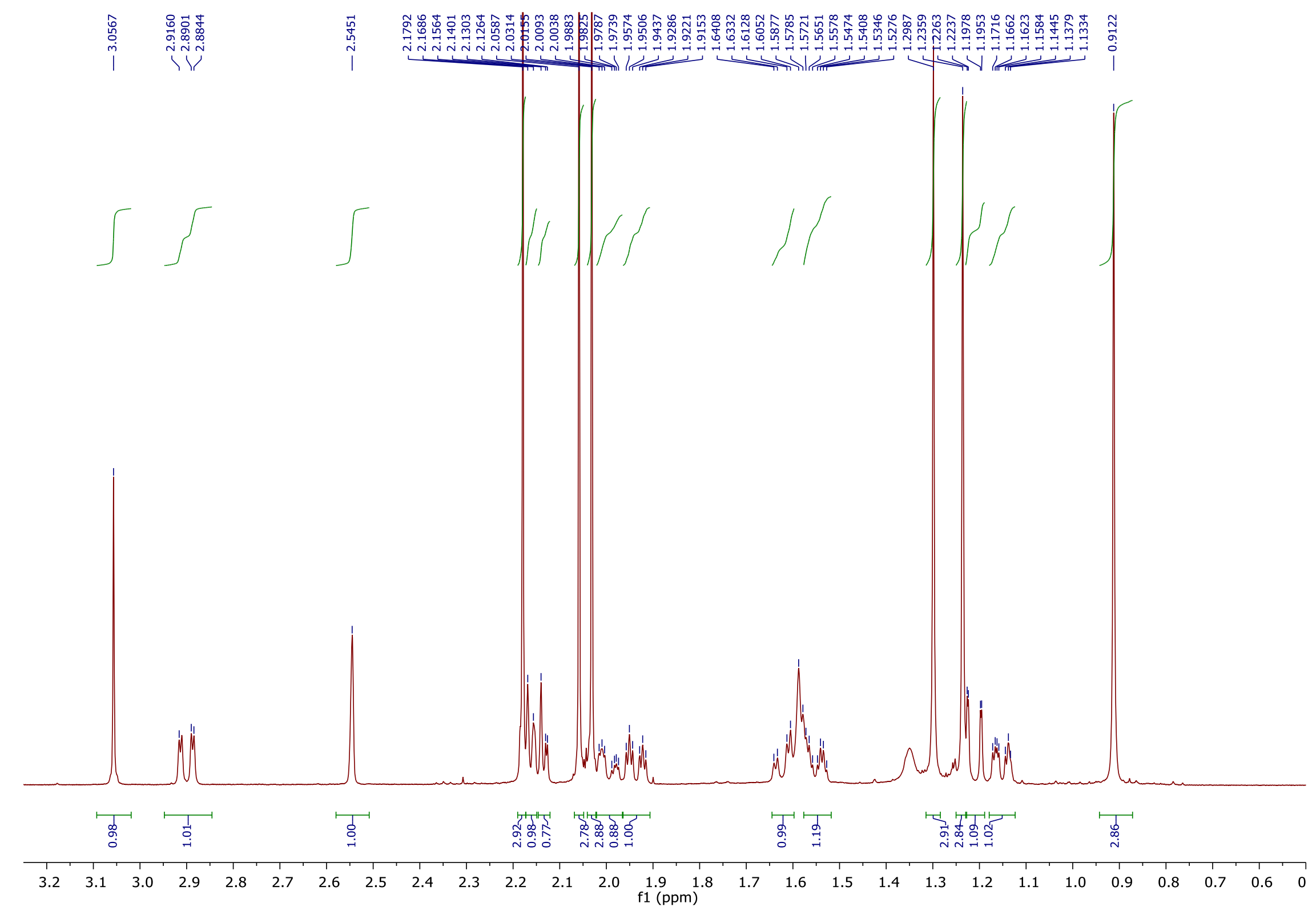



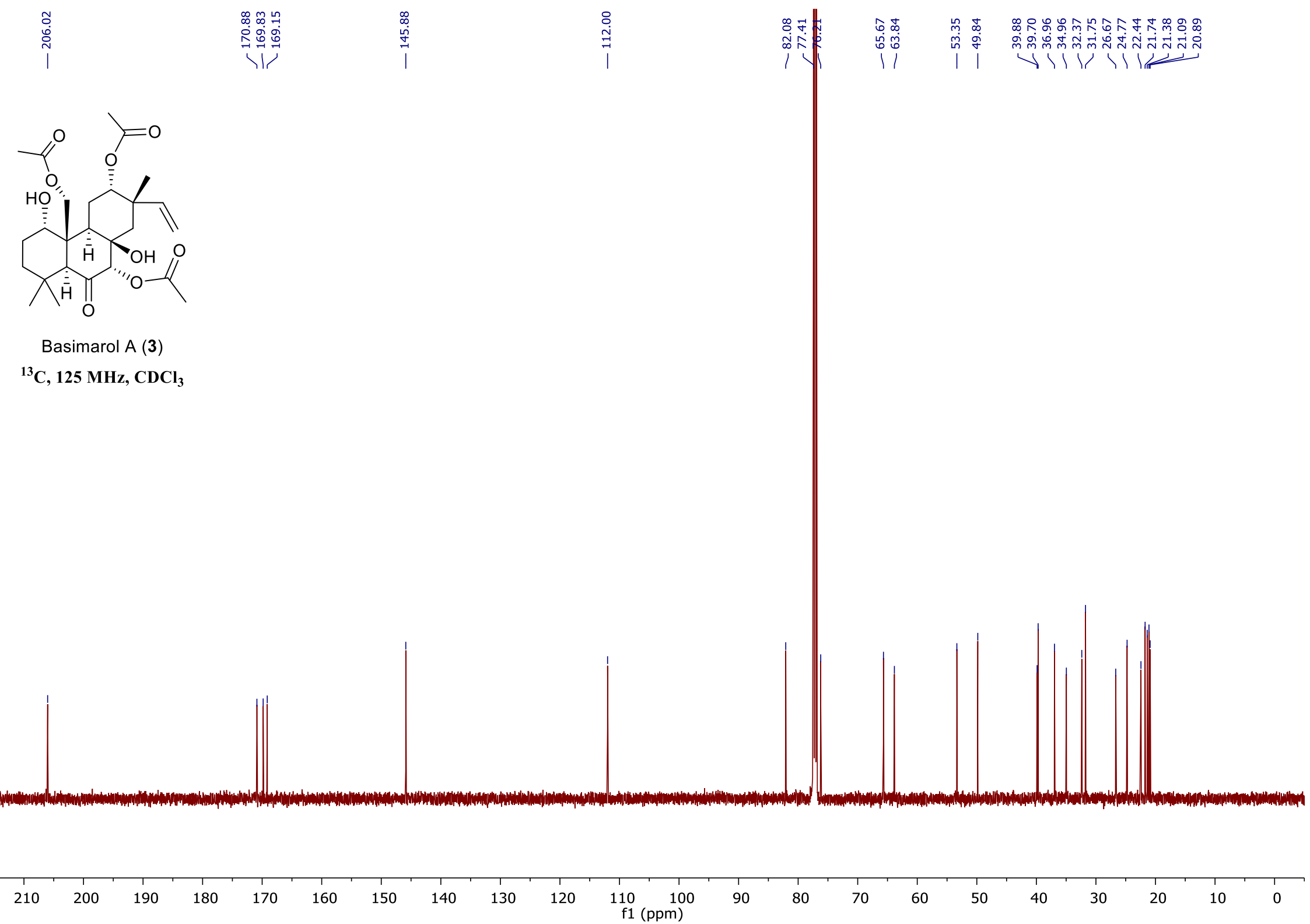


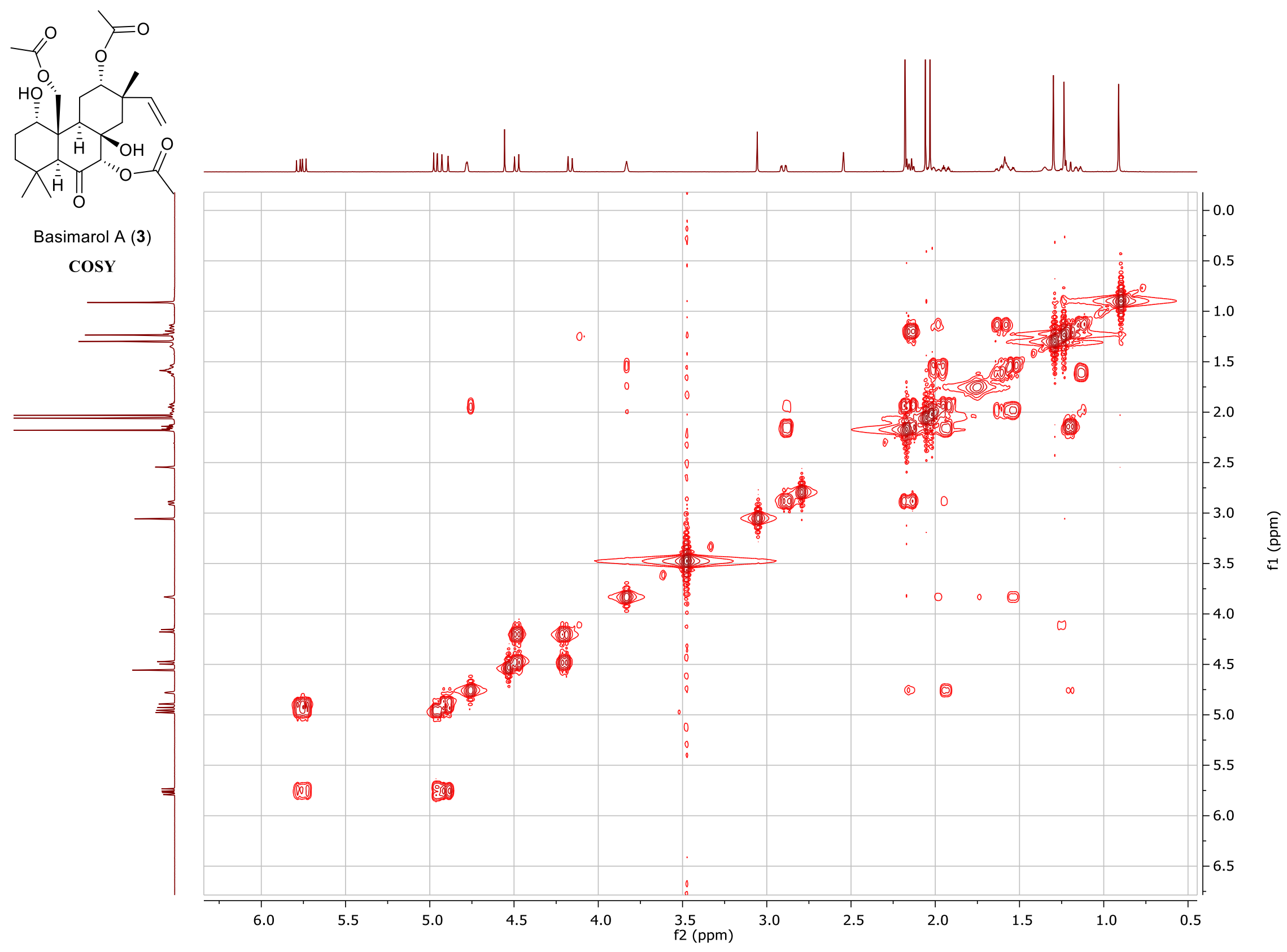





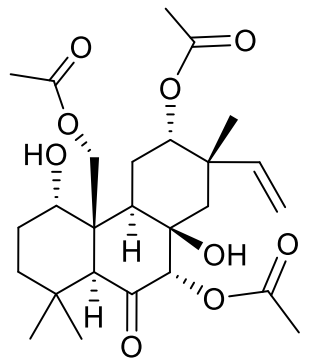

Basimarol A (3) HMBC

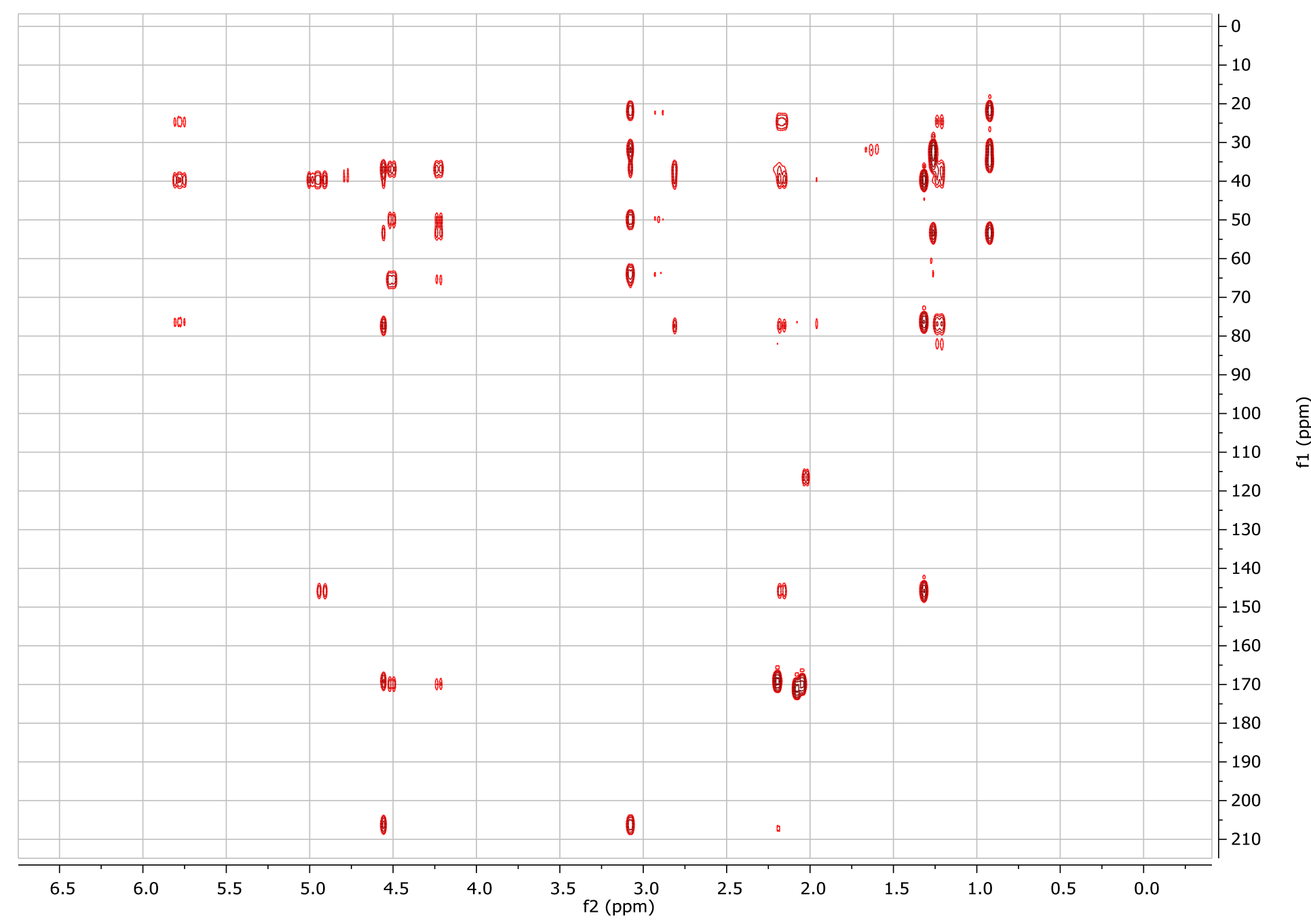




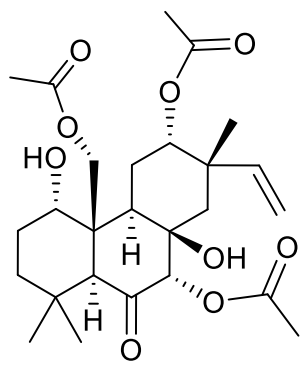

Basimarol A (3)

NOE

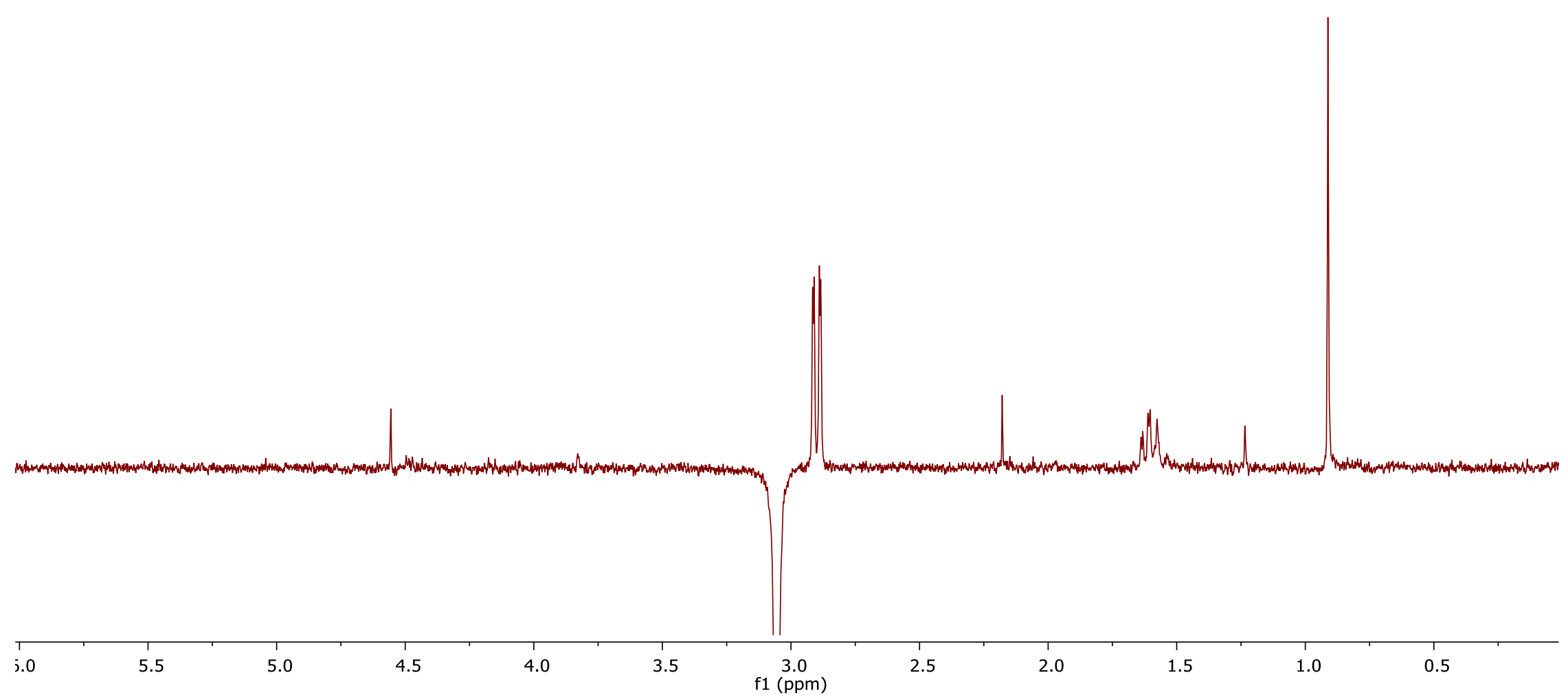




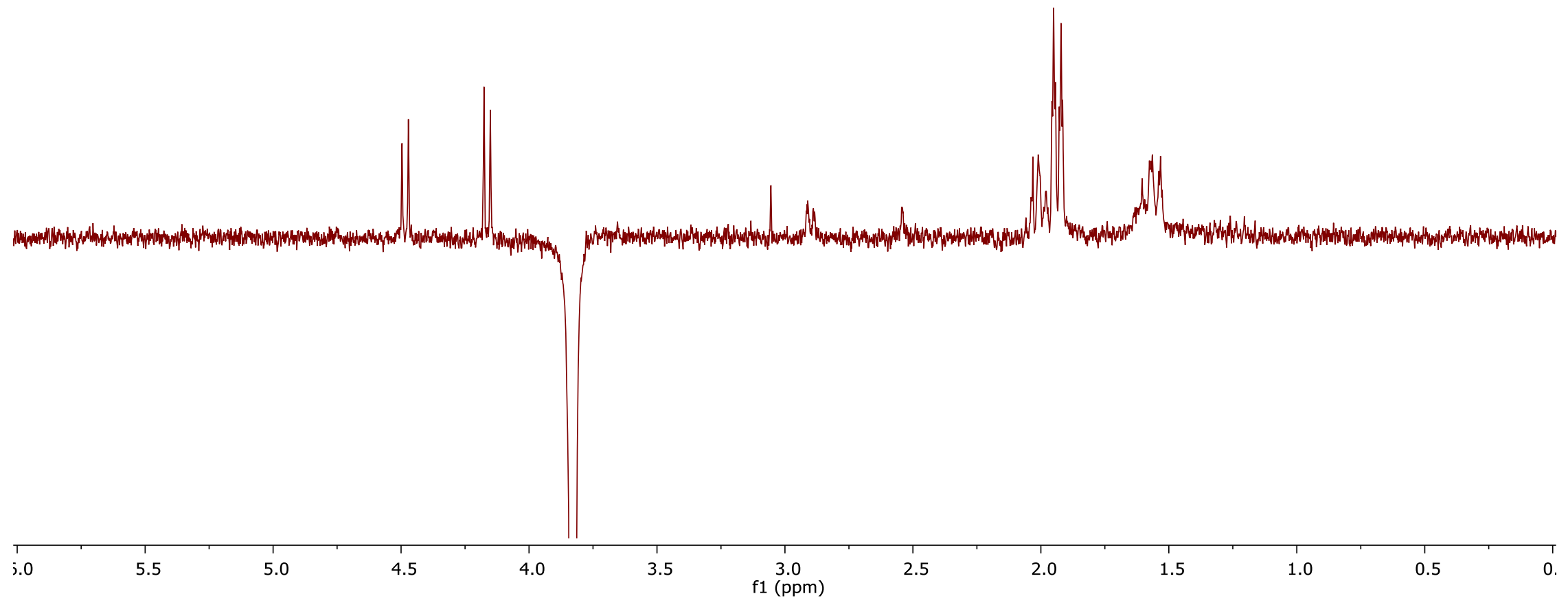




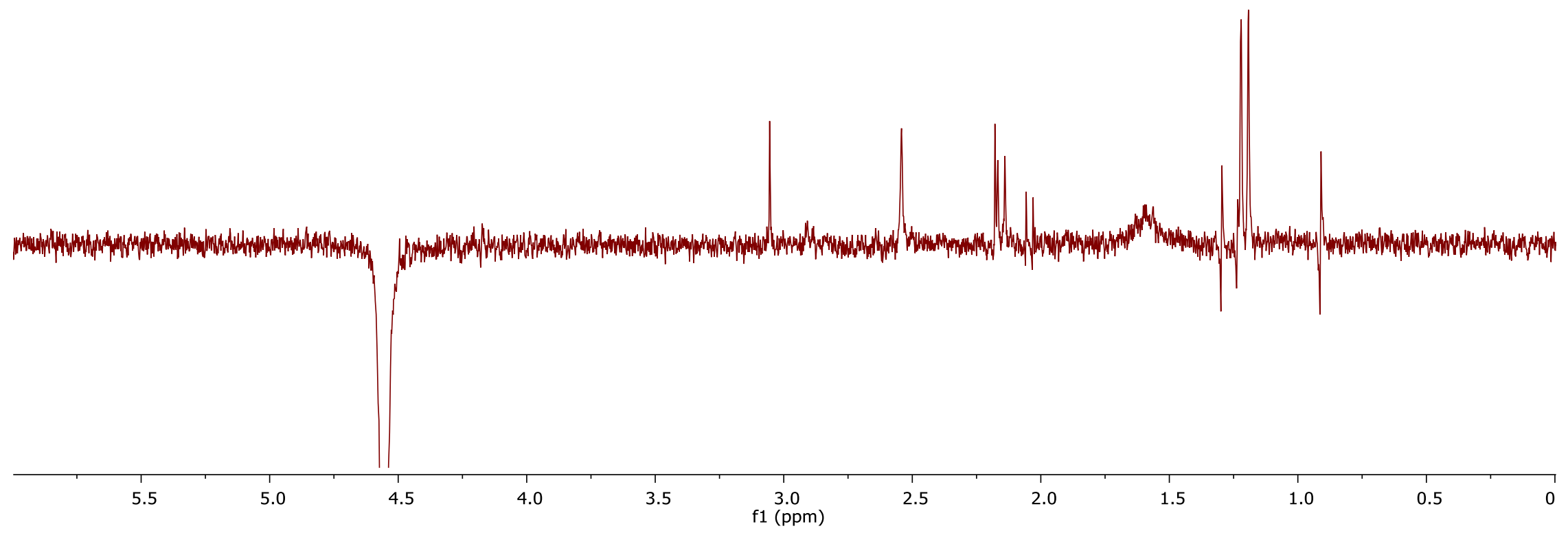




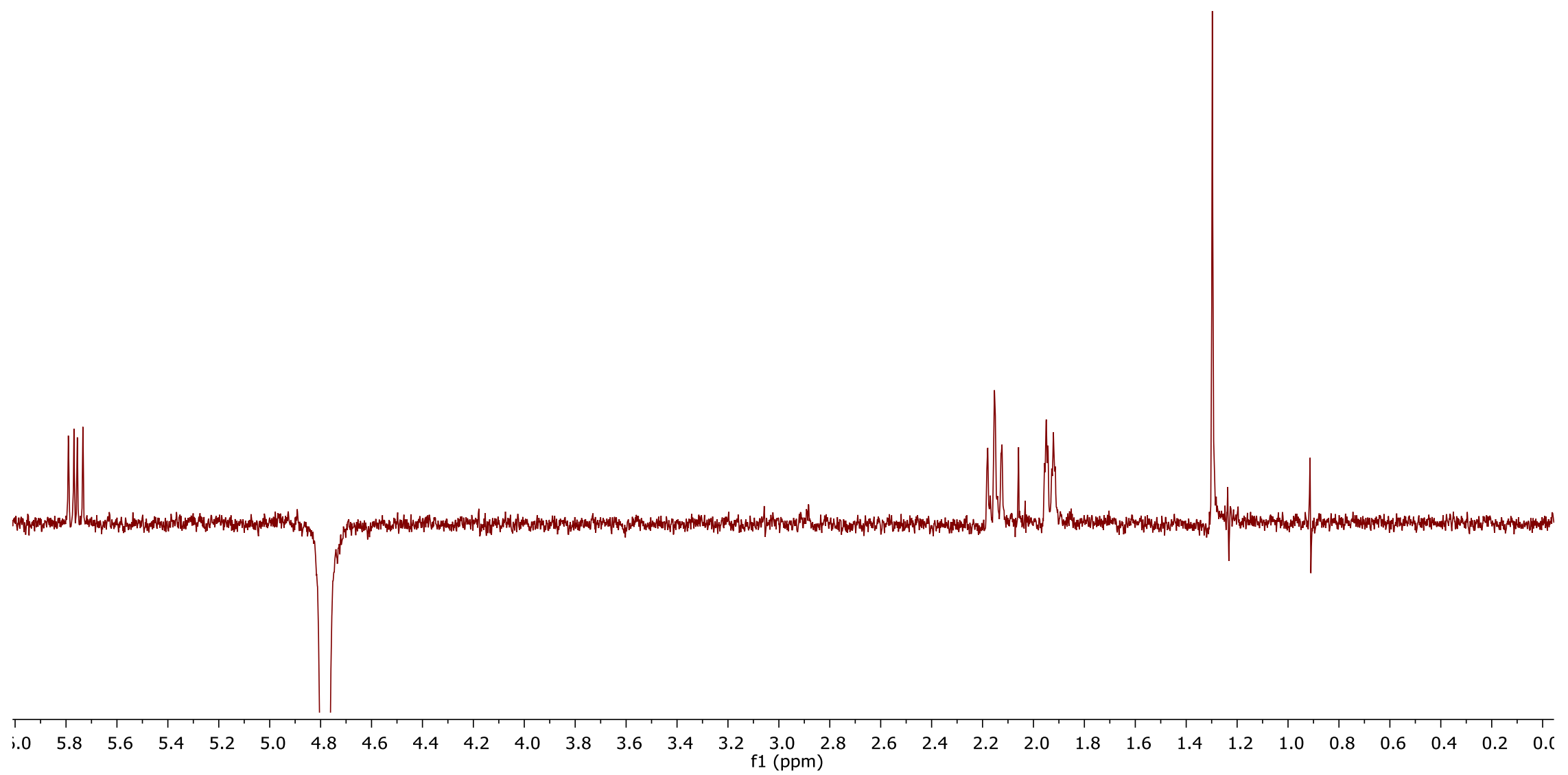

S17 


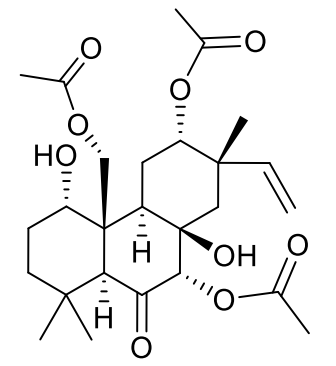

Basimarol A (3) $\begin{gathered}\text { Analys } \\ \text { Date }\end{gathered}$

IR
Student

Friday, 17 November 2017 5:06 PM
PerkinElmer Spectrum Version 10.03.09 Friday, 17 November 2017 5.06 PM

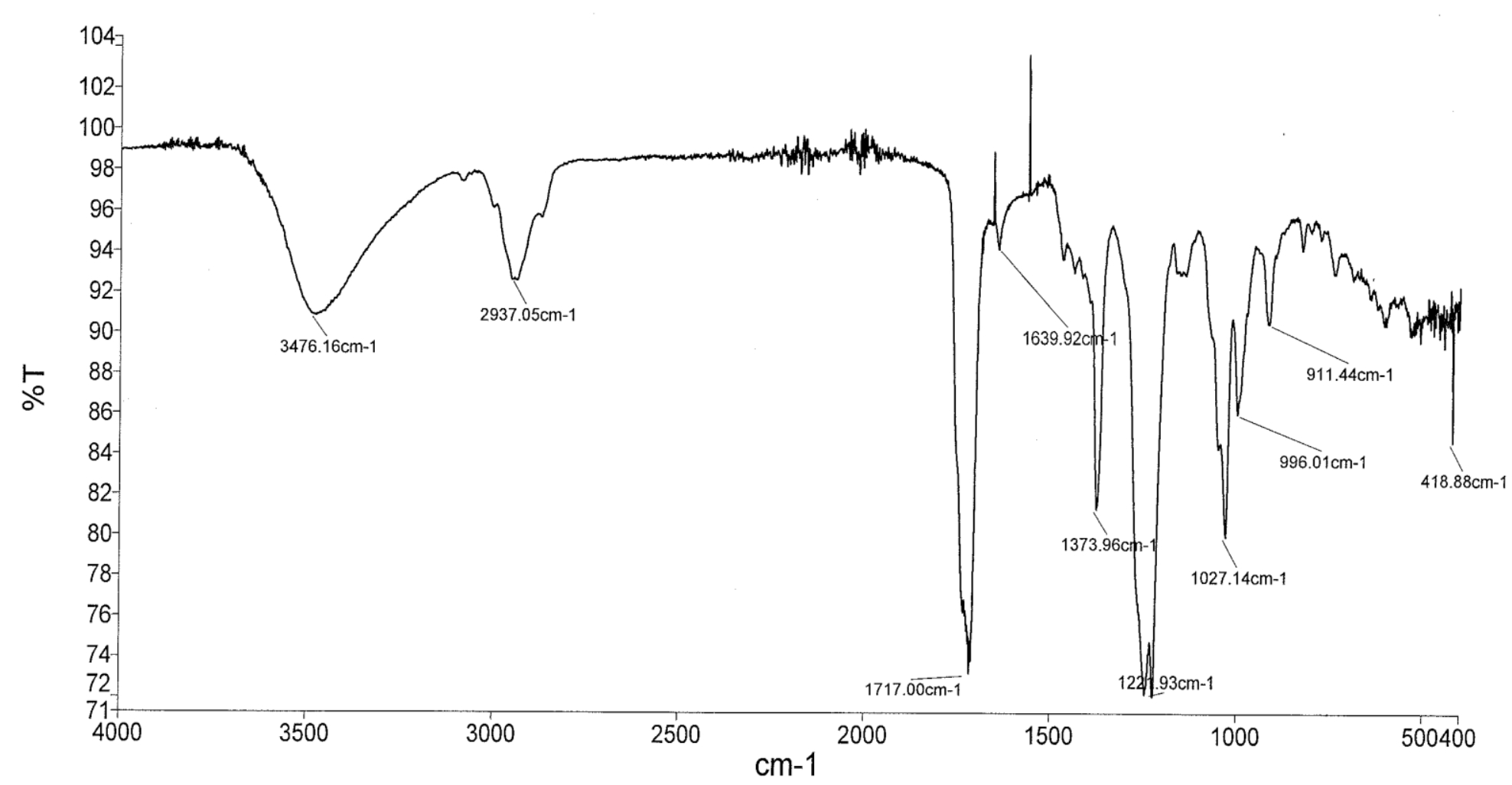


(3nalyst

Basimarol A (3) bate

UV student

Sunday, 13 August 2017 3:43 PM
PerkinEImer UV WinLab Data Processor and Viewer Version 1.00.00 13/08/2017 3:43 PM

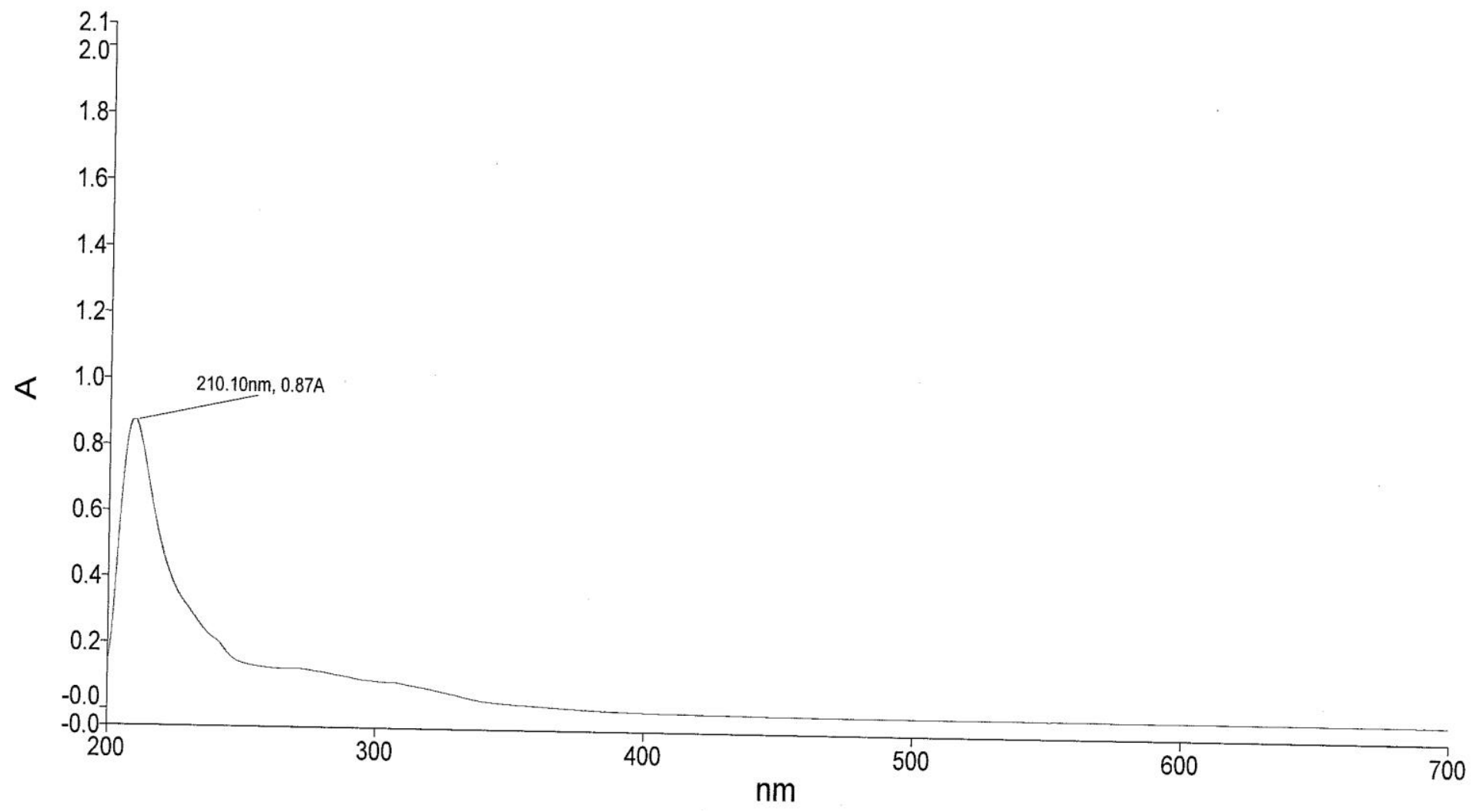




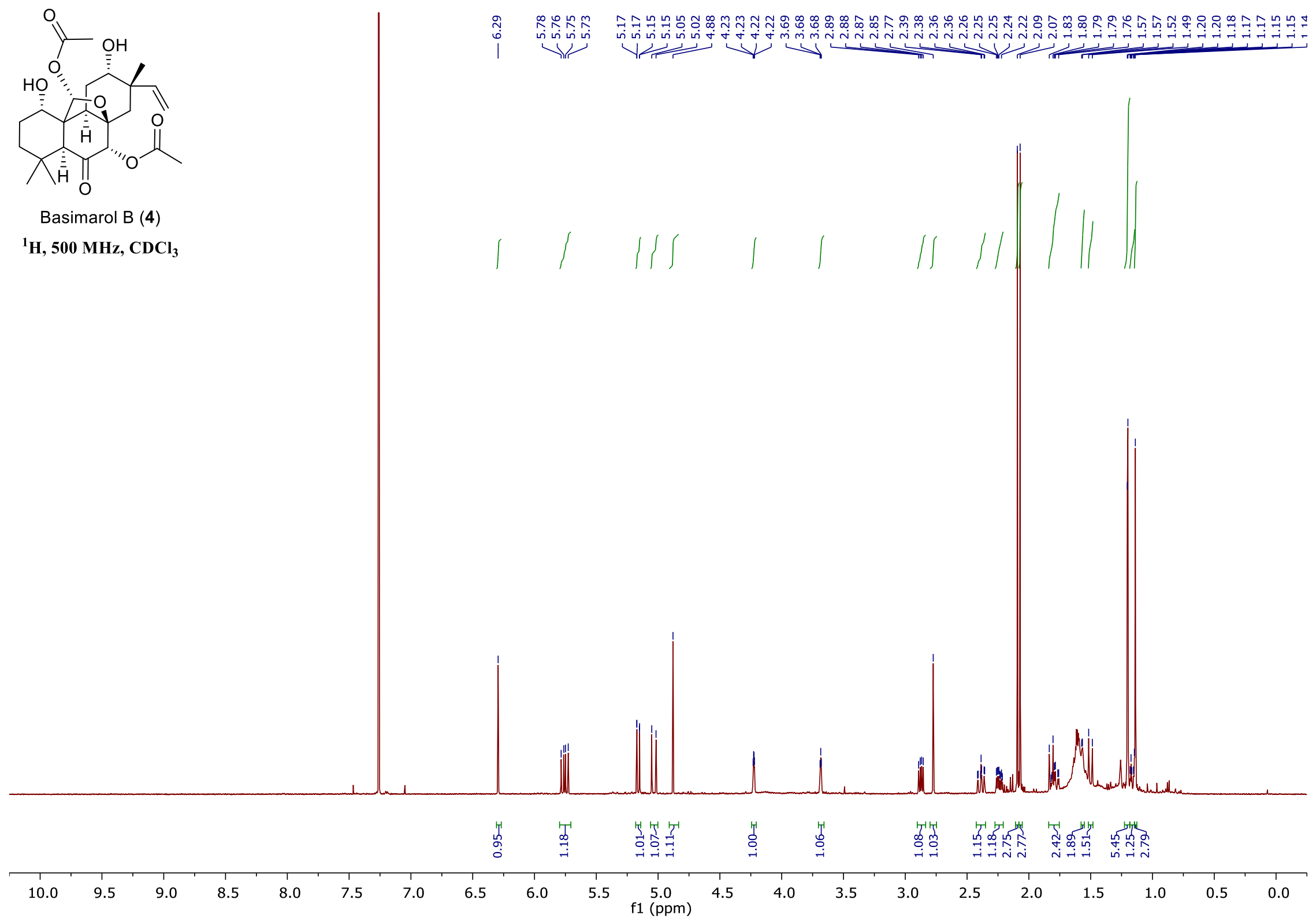




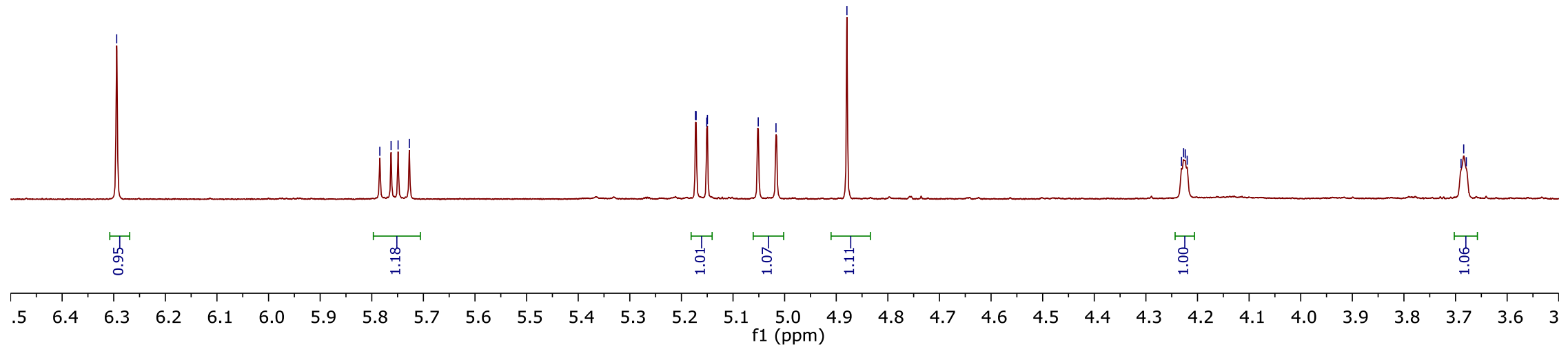




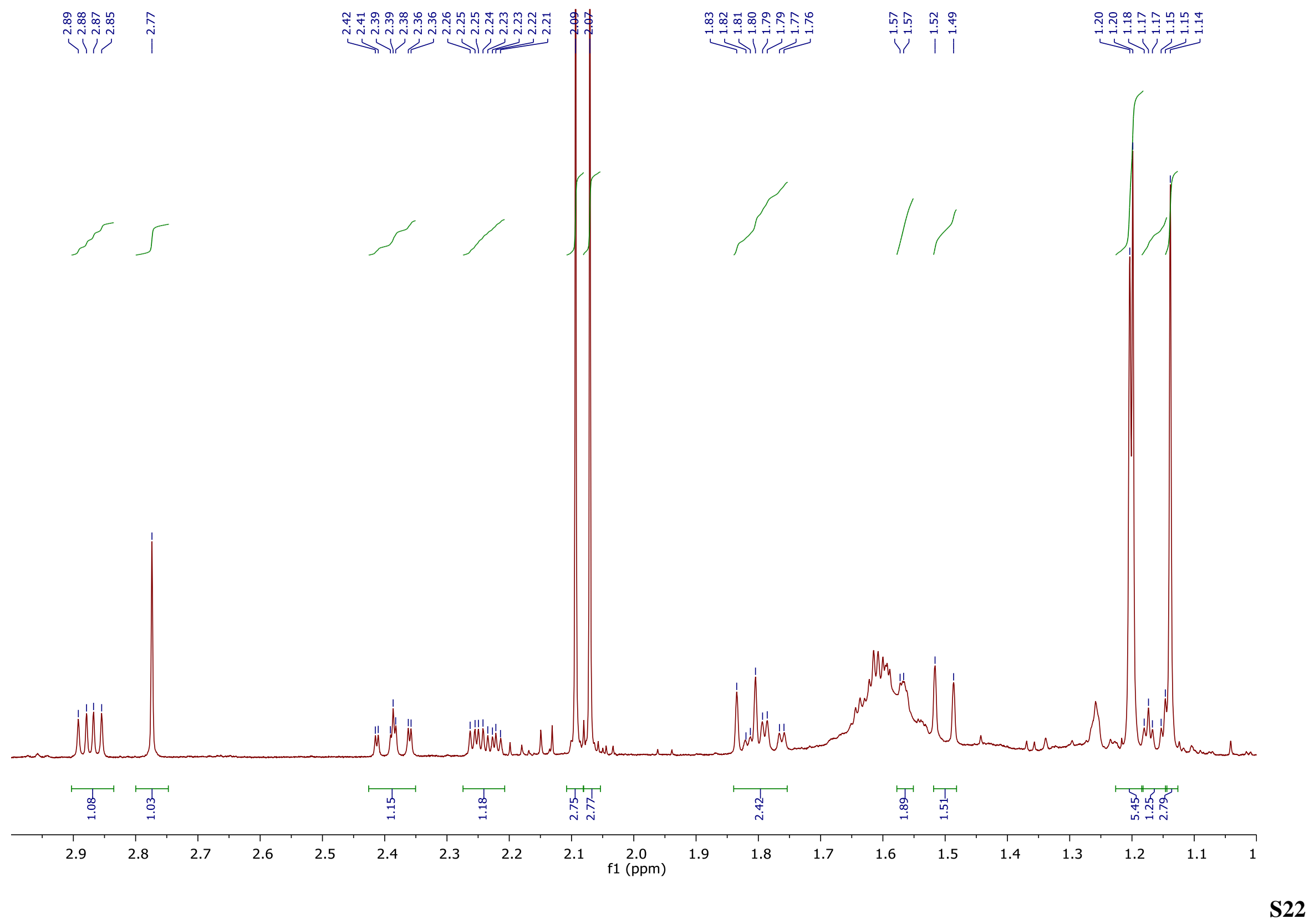




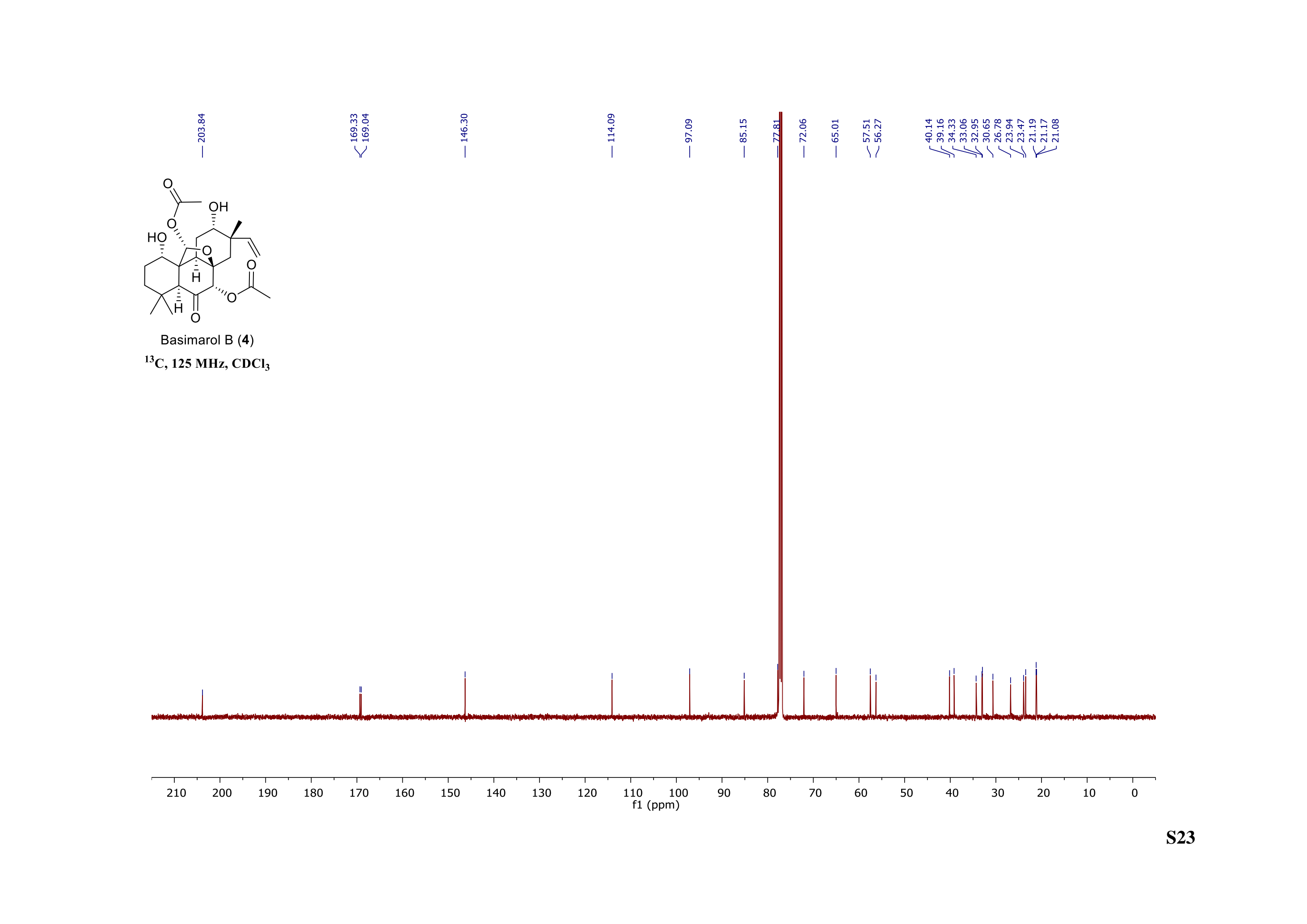




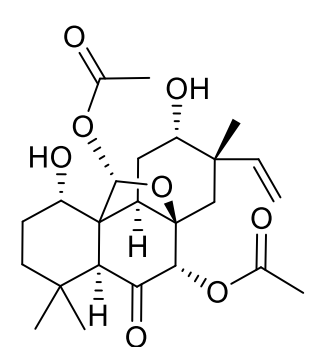

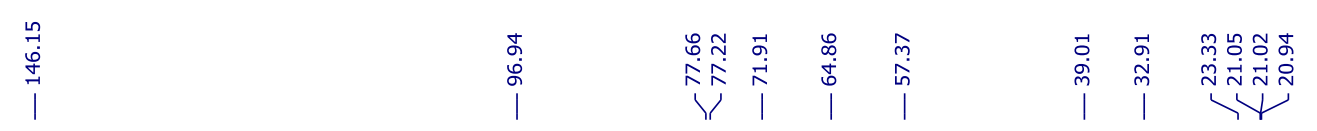

Basimarol B (4)

DEPT

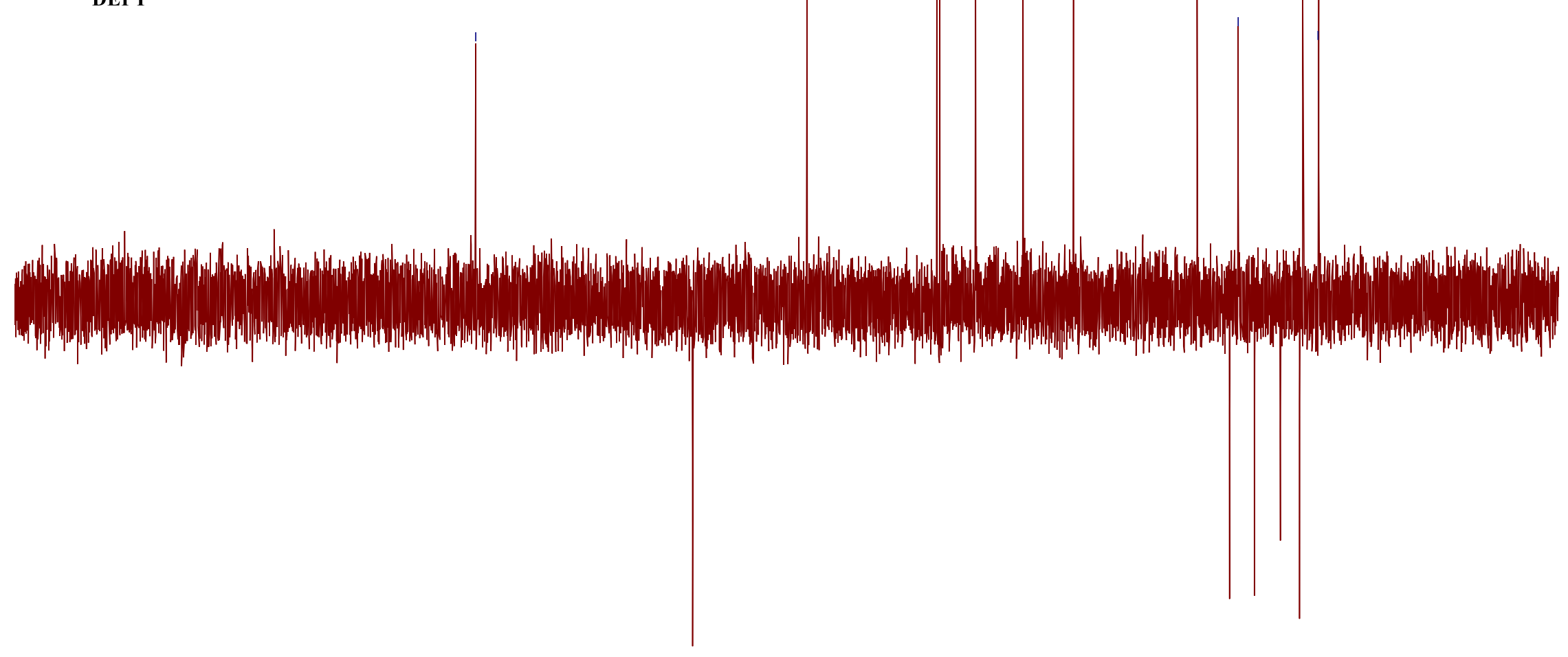

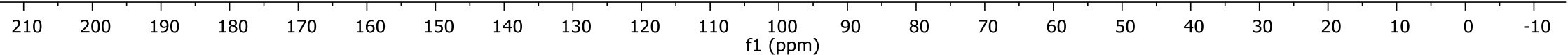




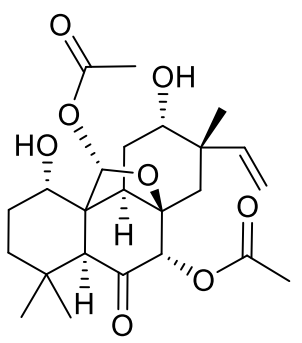

Basimarol B (4) COSY
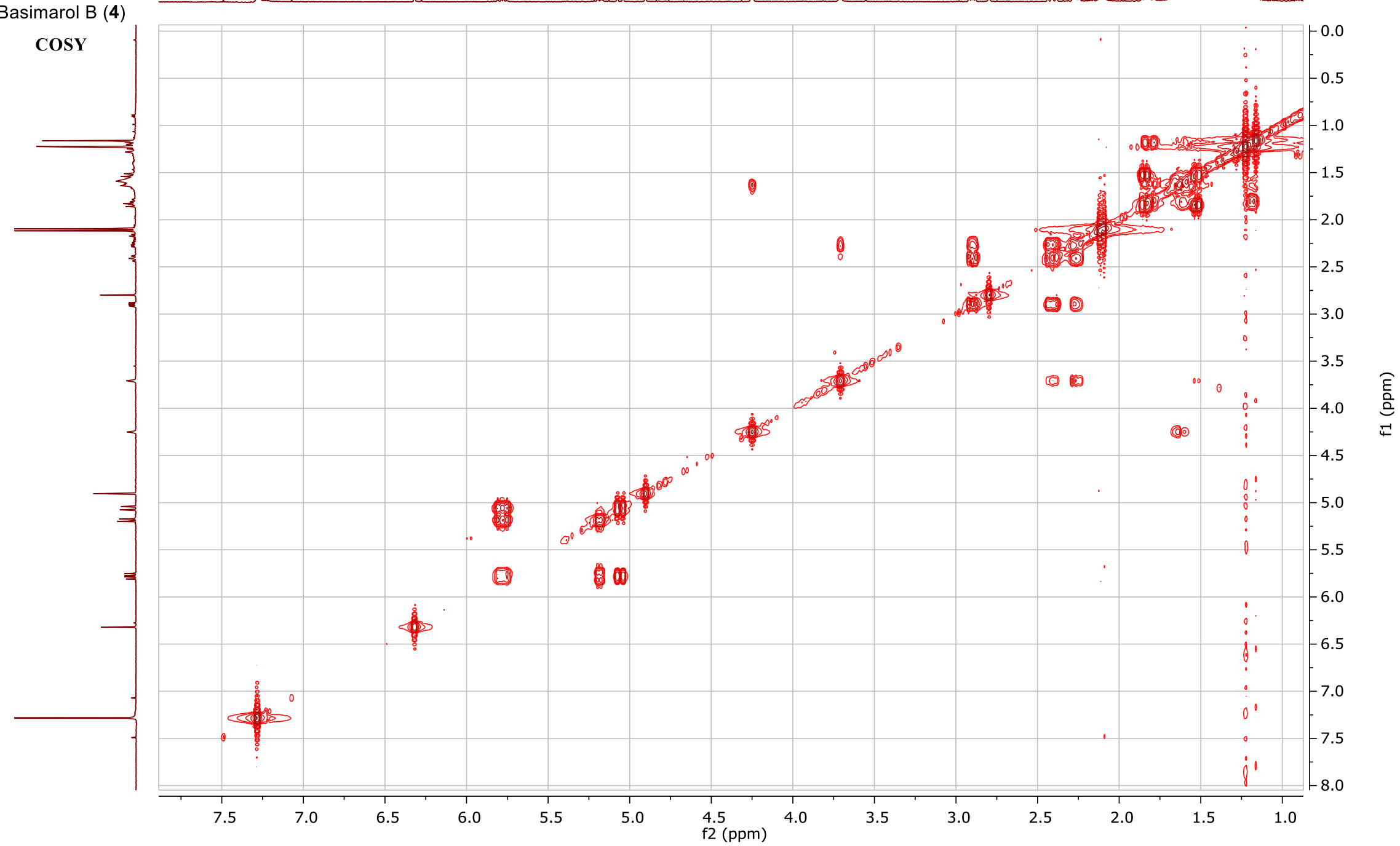


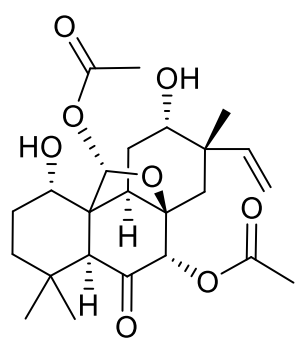

Basimarol B (4)

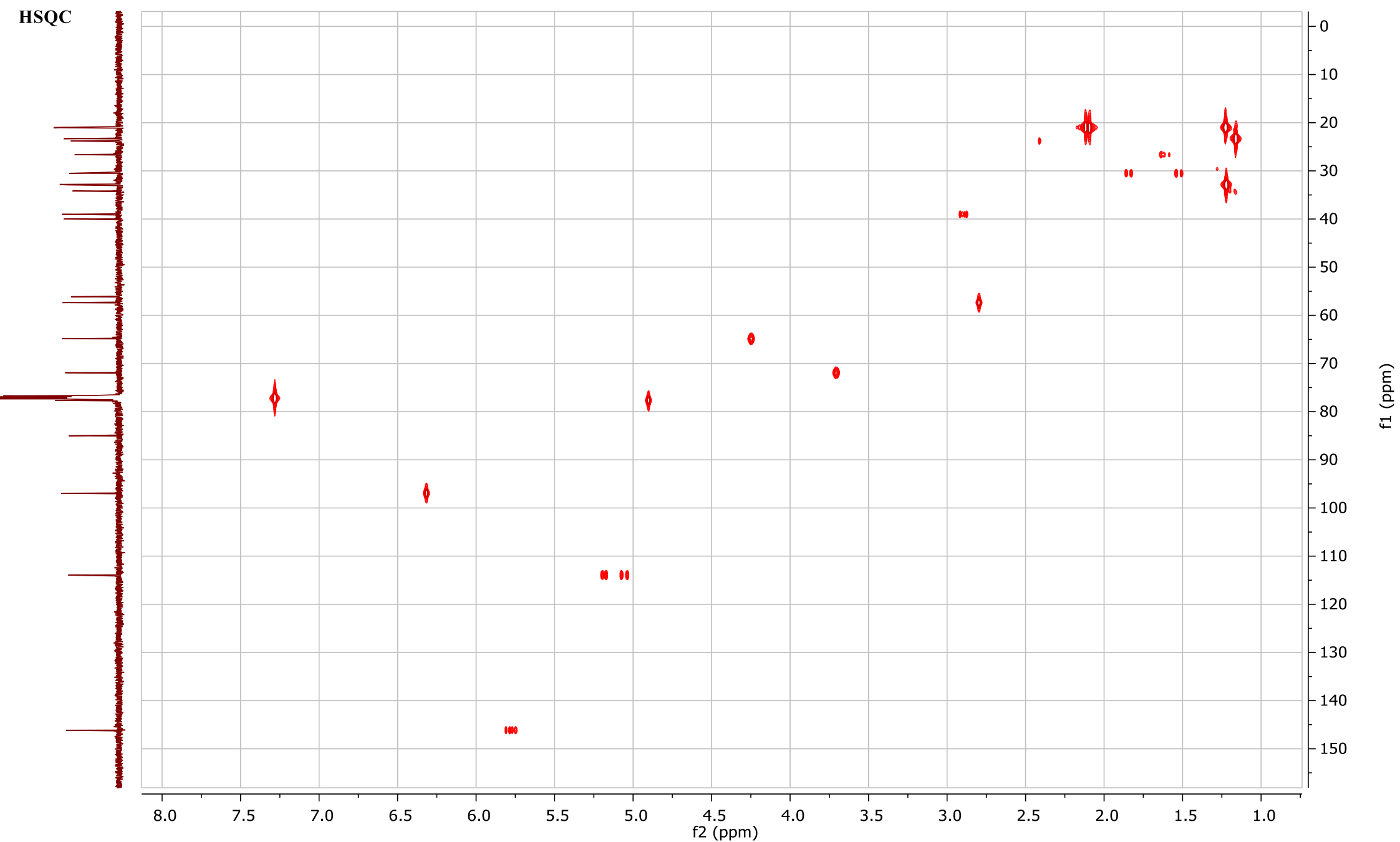



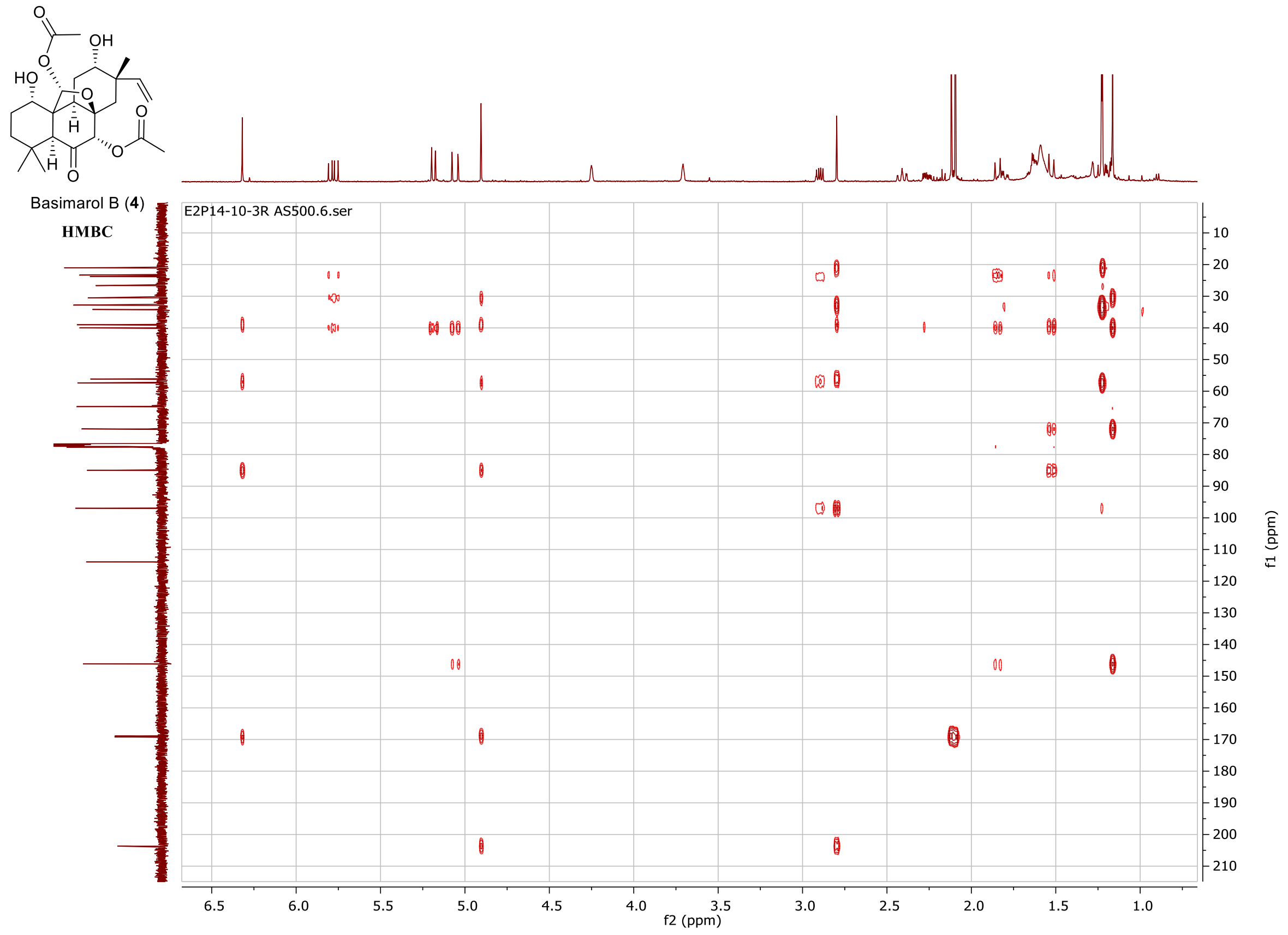


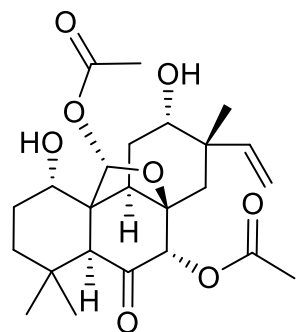

Basimarol B (4)

NOE

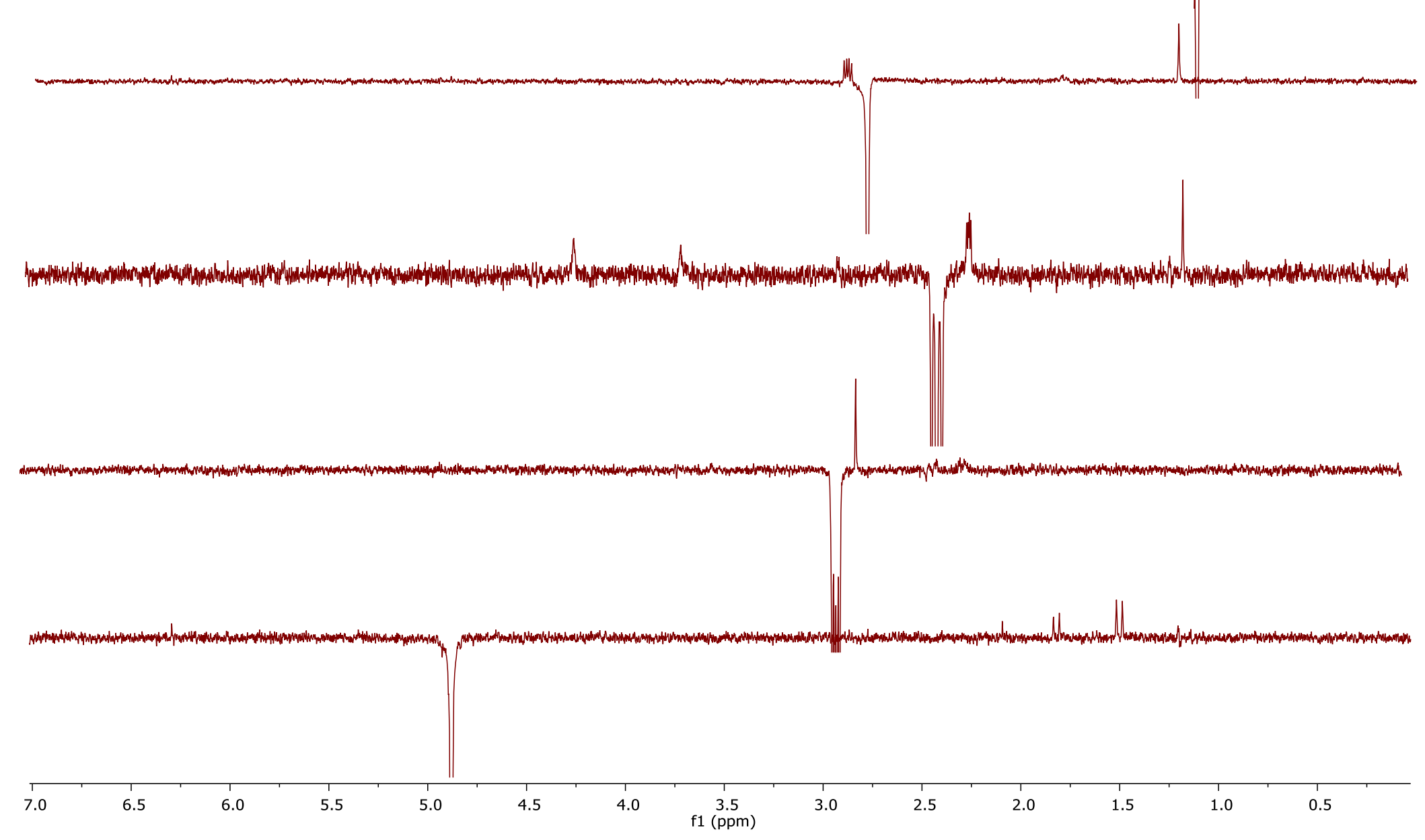




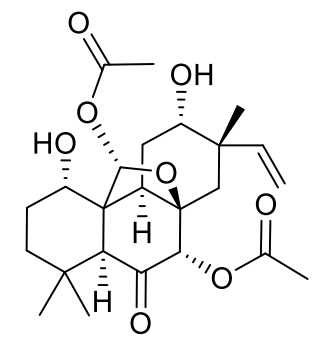

Basimarol B (4)

IR Analyst

Student

PerkinElmer Spectrum Version 10.03.09 Sunday, 13 August 2017 2:41 PM

Date

Sunday, 13 August 2017 2:41 PM

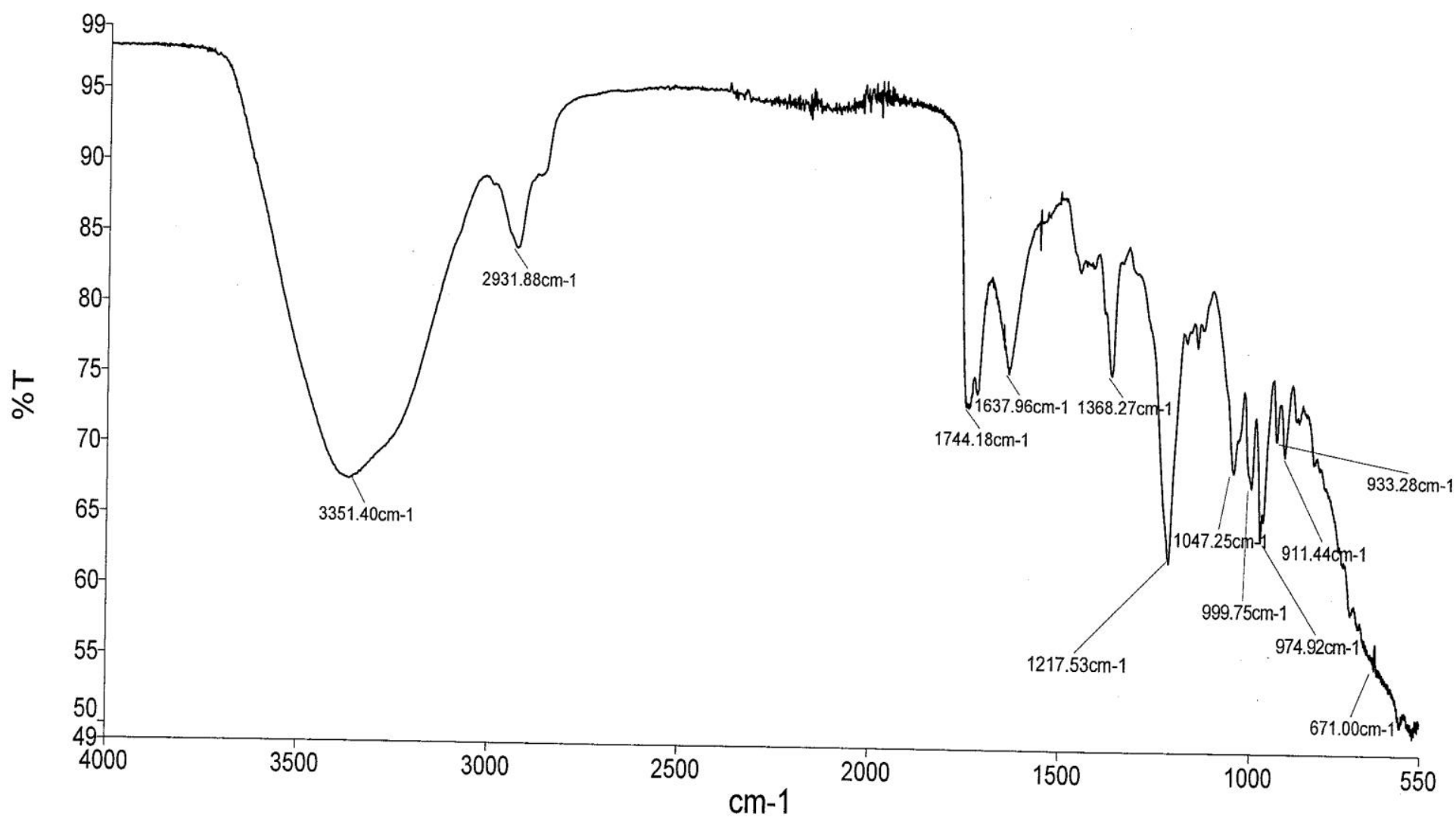




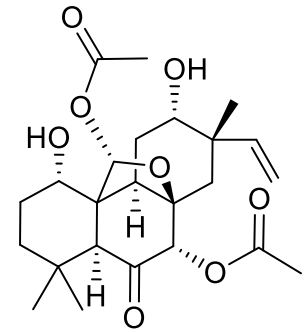

Basimarol B (4)

UV Analyst

Date

student

Sunday, 13 August 2017 3:40 PM

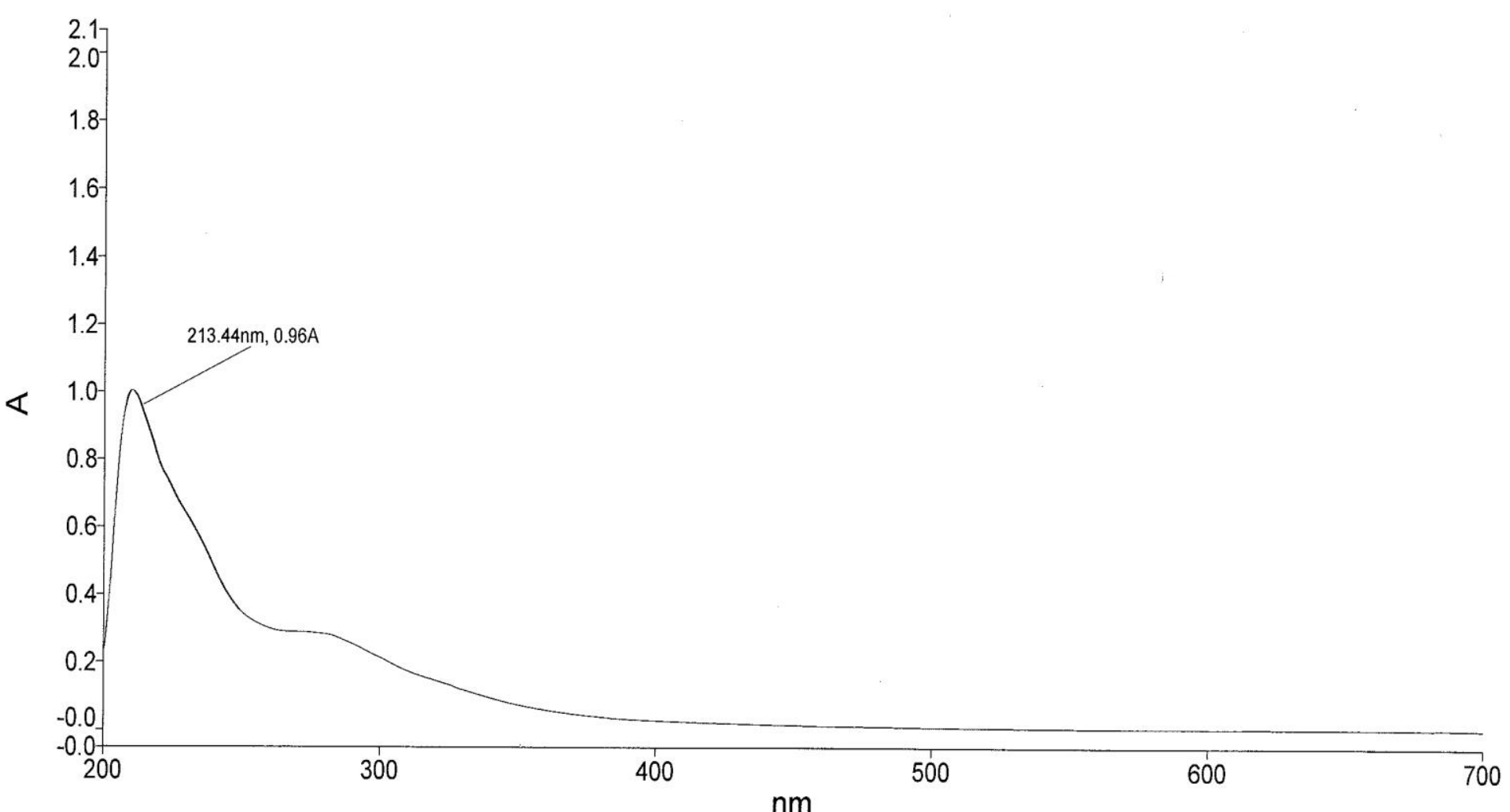




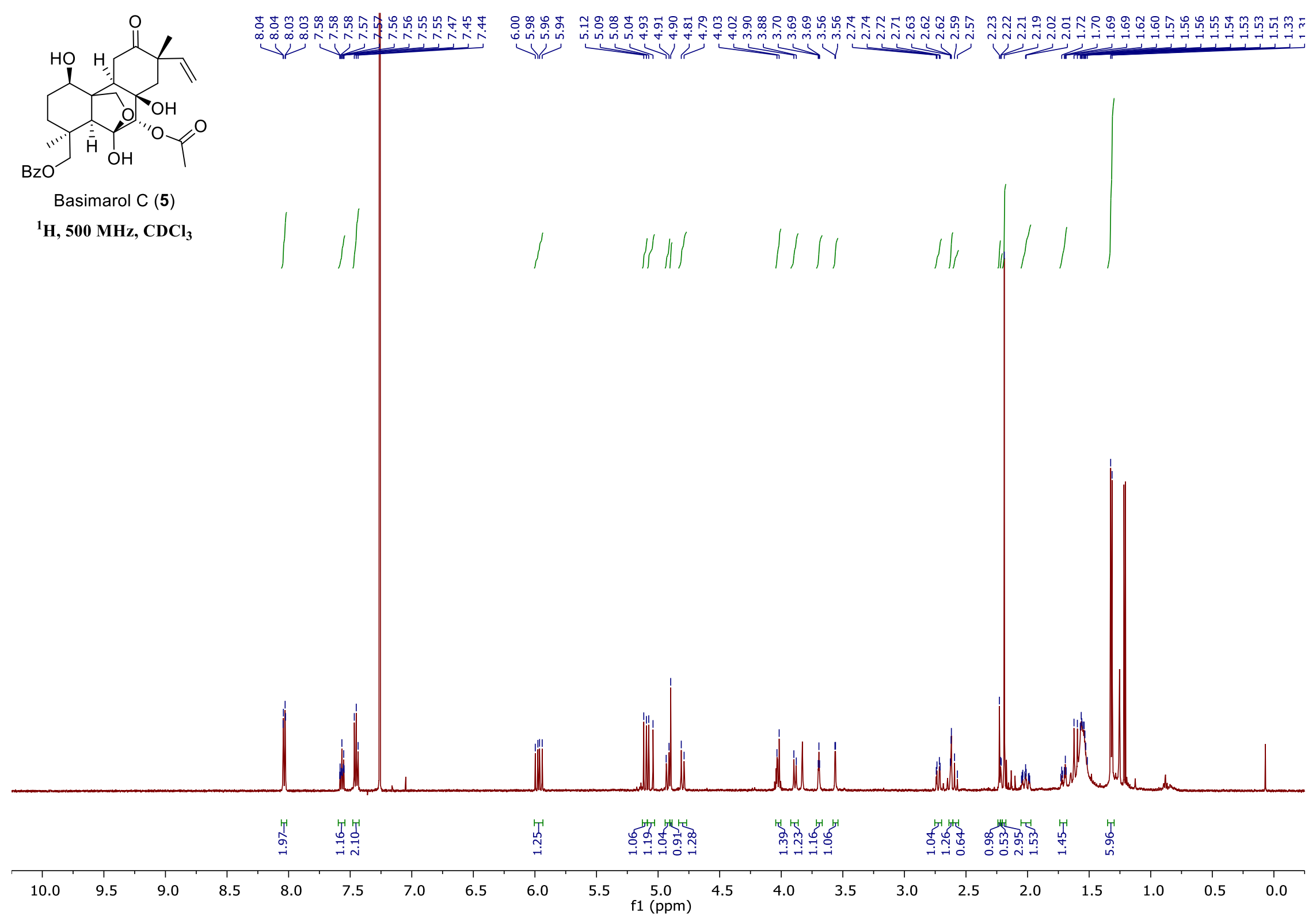




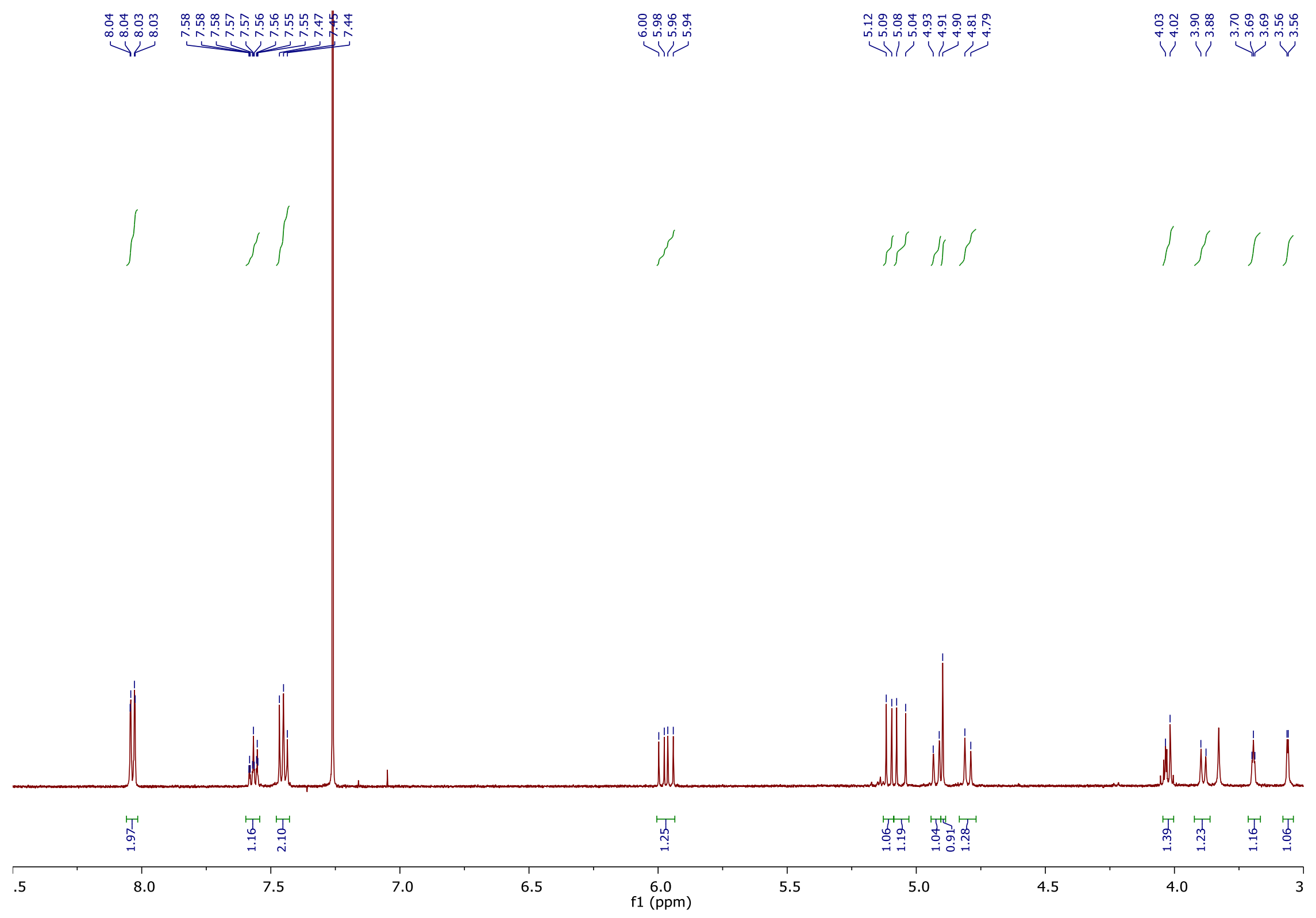




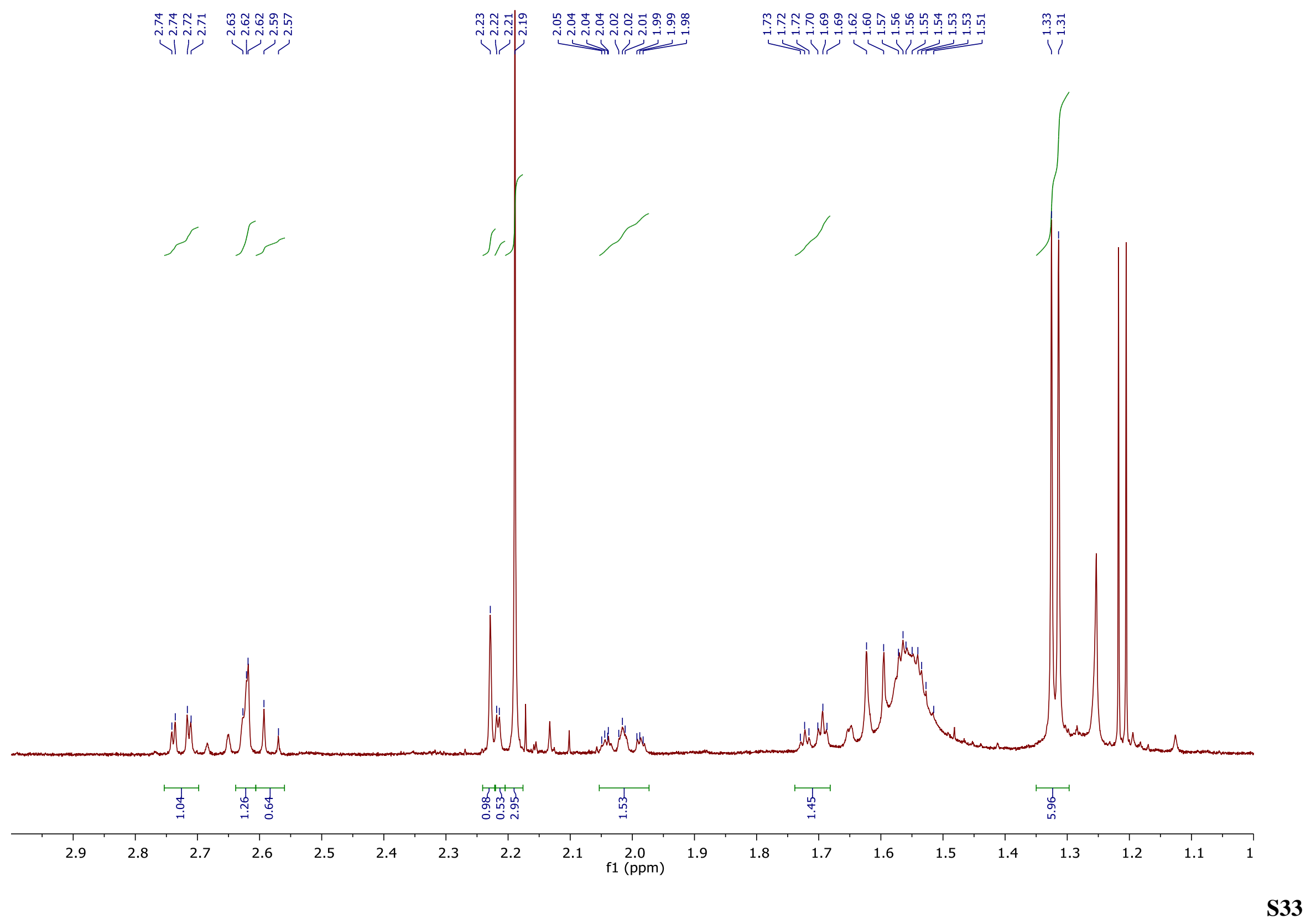




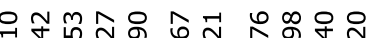

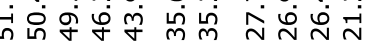

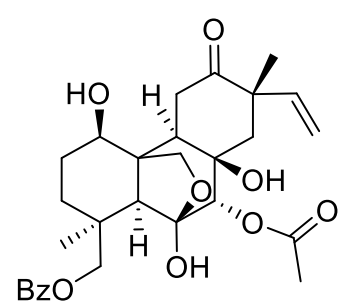

Basimarol C (5)

${ }^{13} \mathrm{C}, 125 \mathrm{MHz}, \mathrm{CDCl}_{3}$
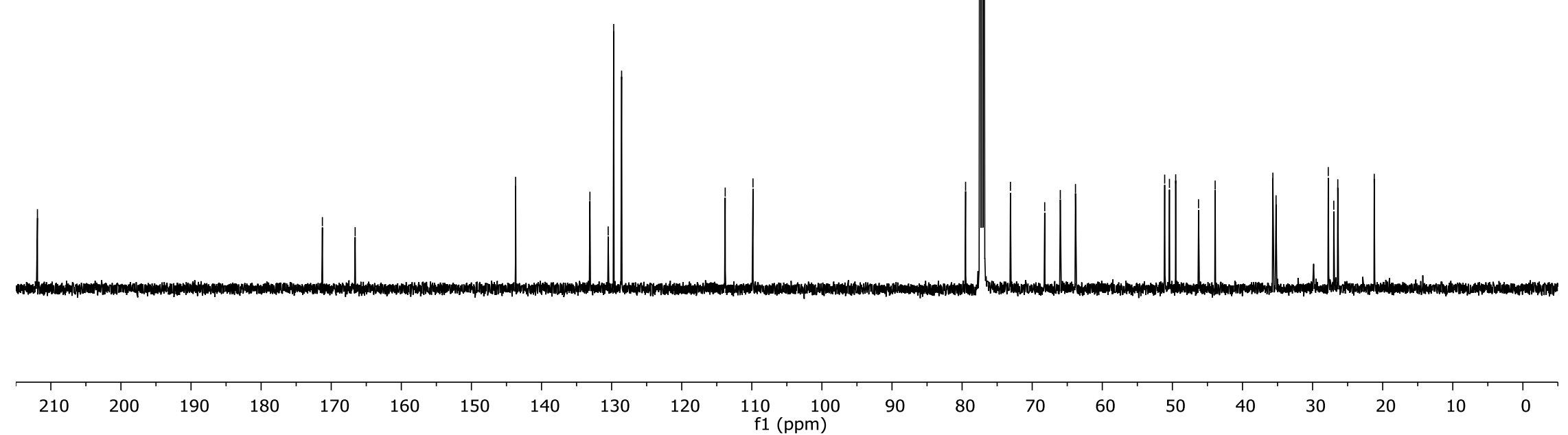

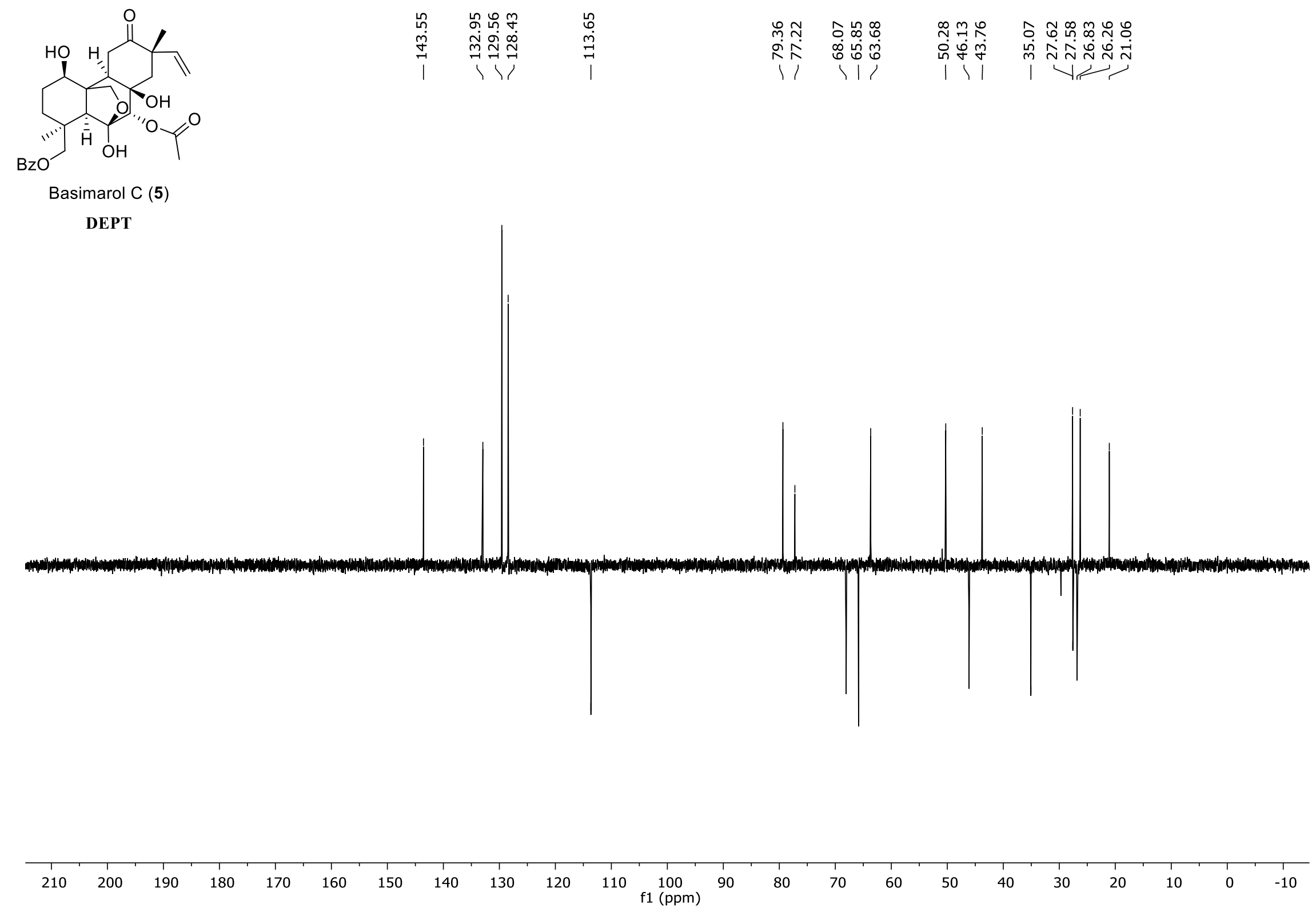


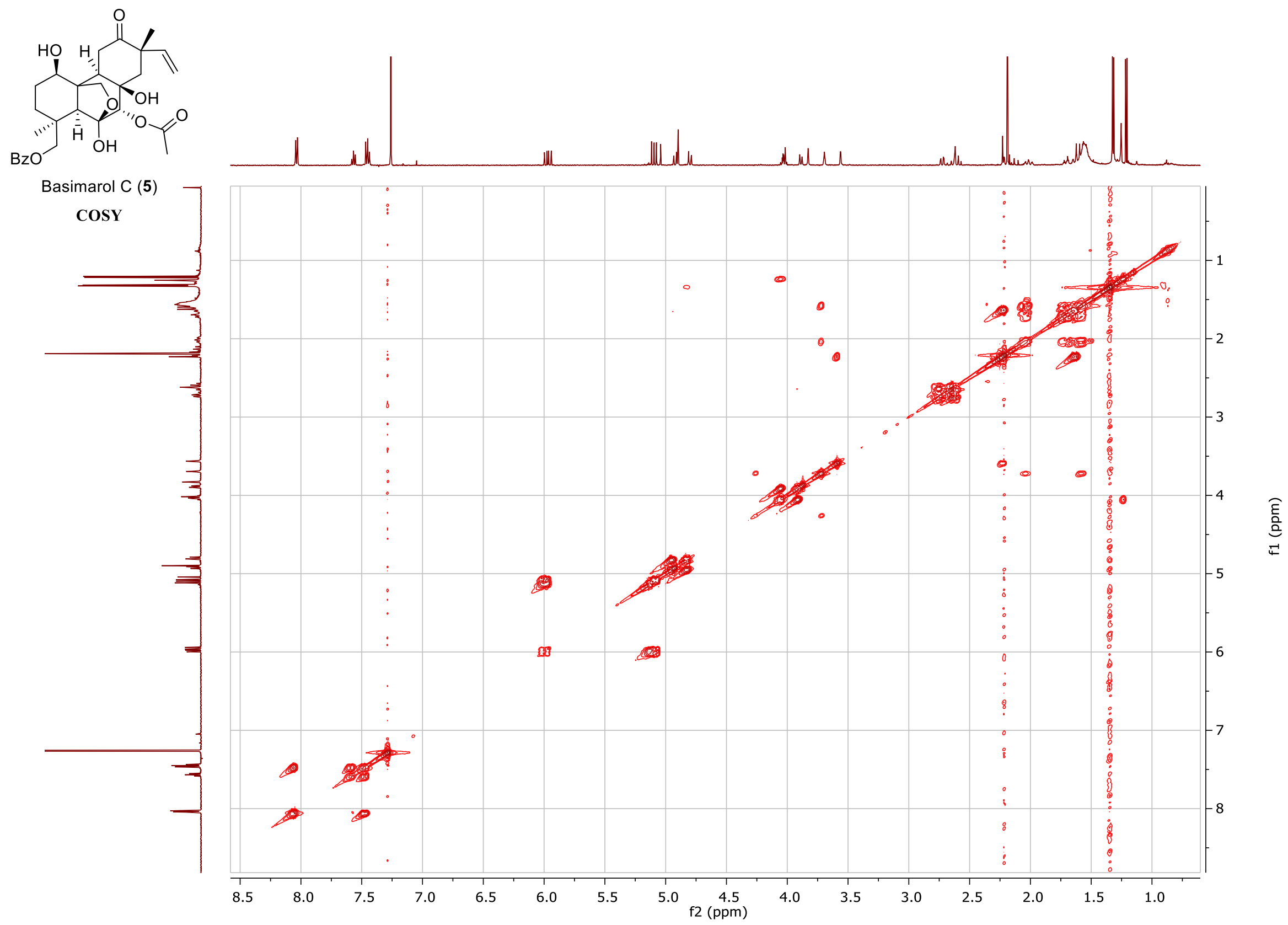

S36 


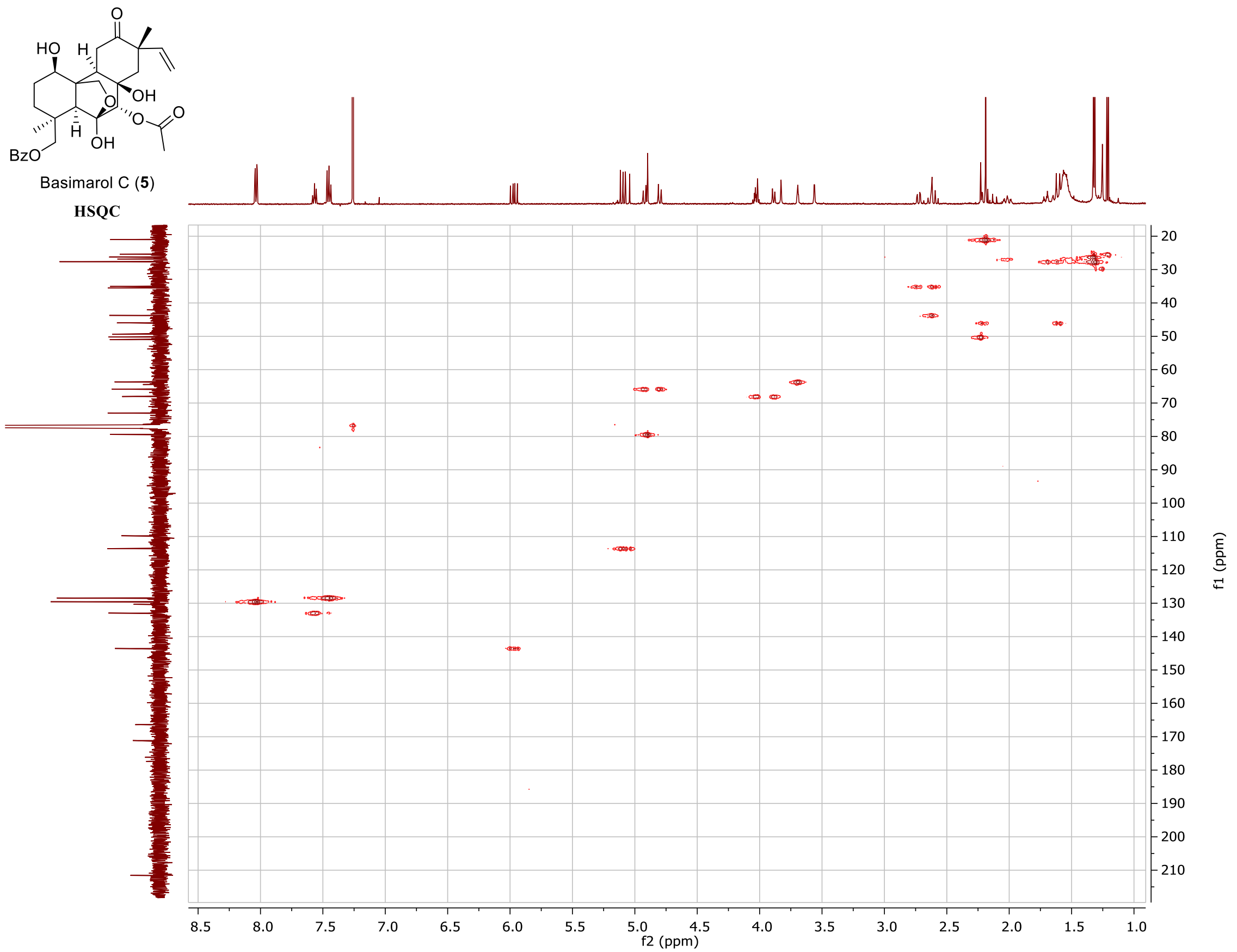

S37 


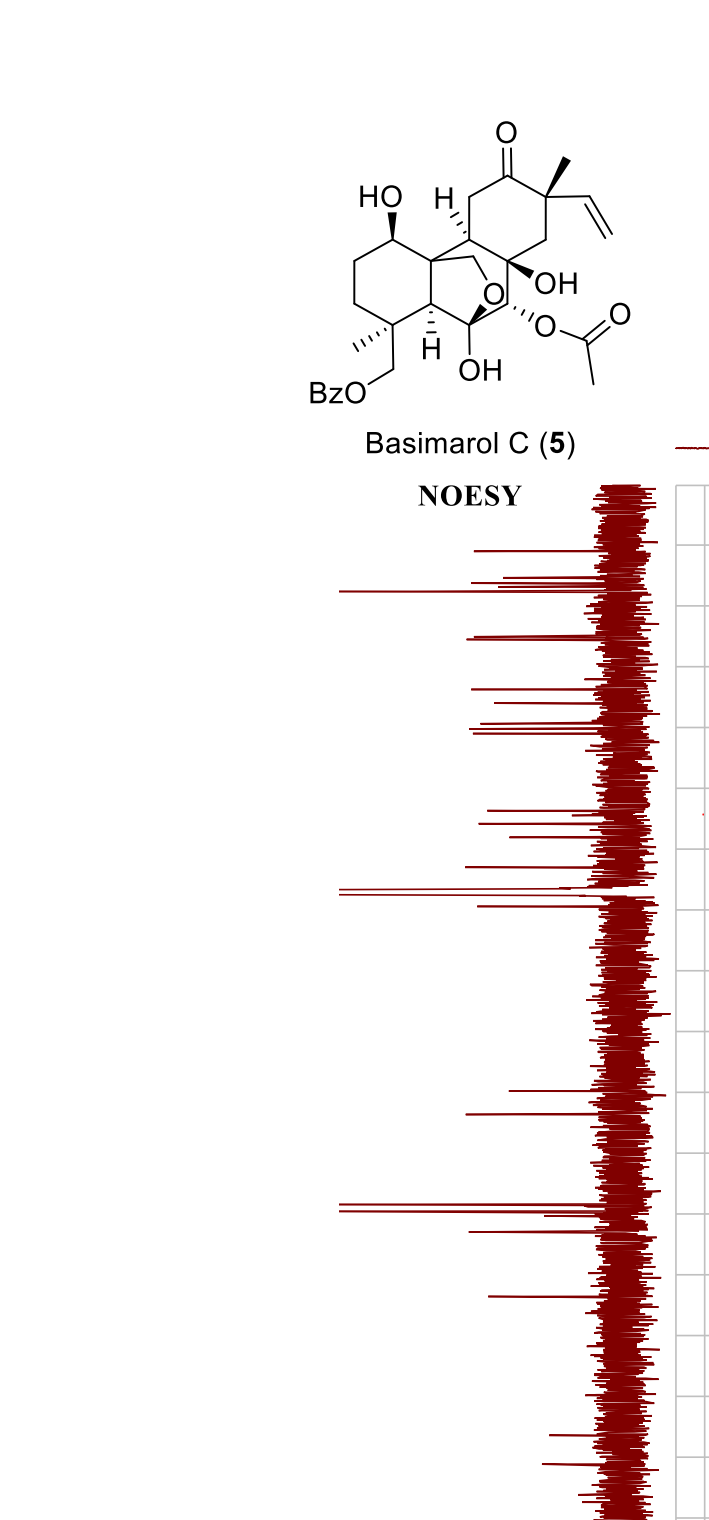




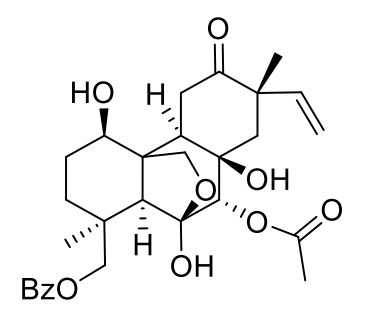

Basimarol C (5)

$$
\mathbf{I R}_{\text {Analyst }}
$$

Administrator

Friday, 8 December 2017 1:41 PM

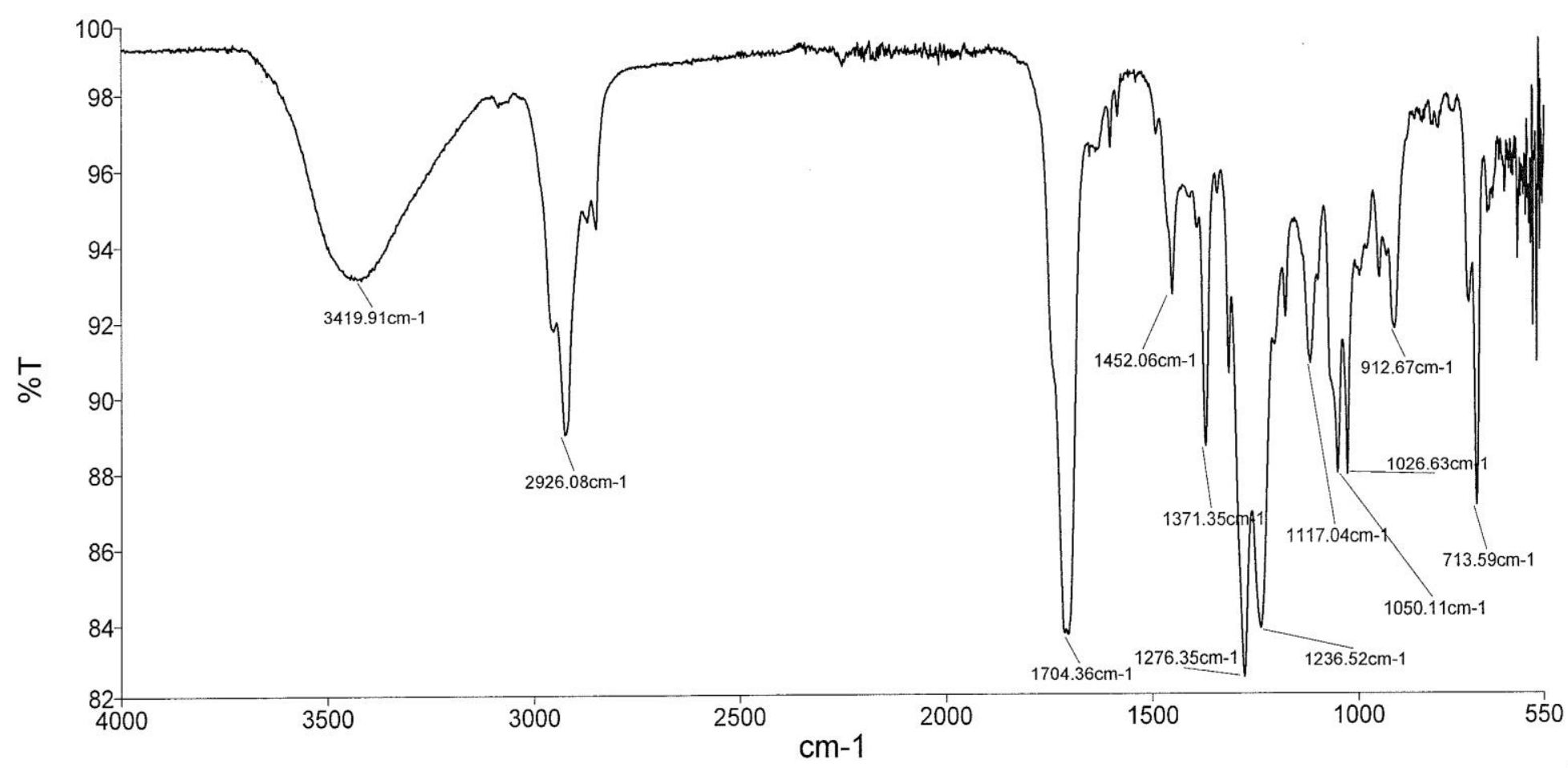




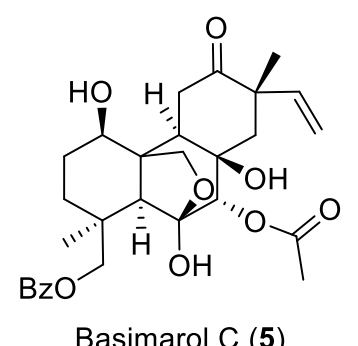

UV Analyst

$$
\text { Date }
$$

student

Wednesday, 17 January 2018 2:37 PM
PerkinElmer UV WinLab Data Processor and Viewer Version 1.00 .00 17/01/2018 2:37 PM

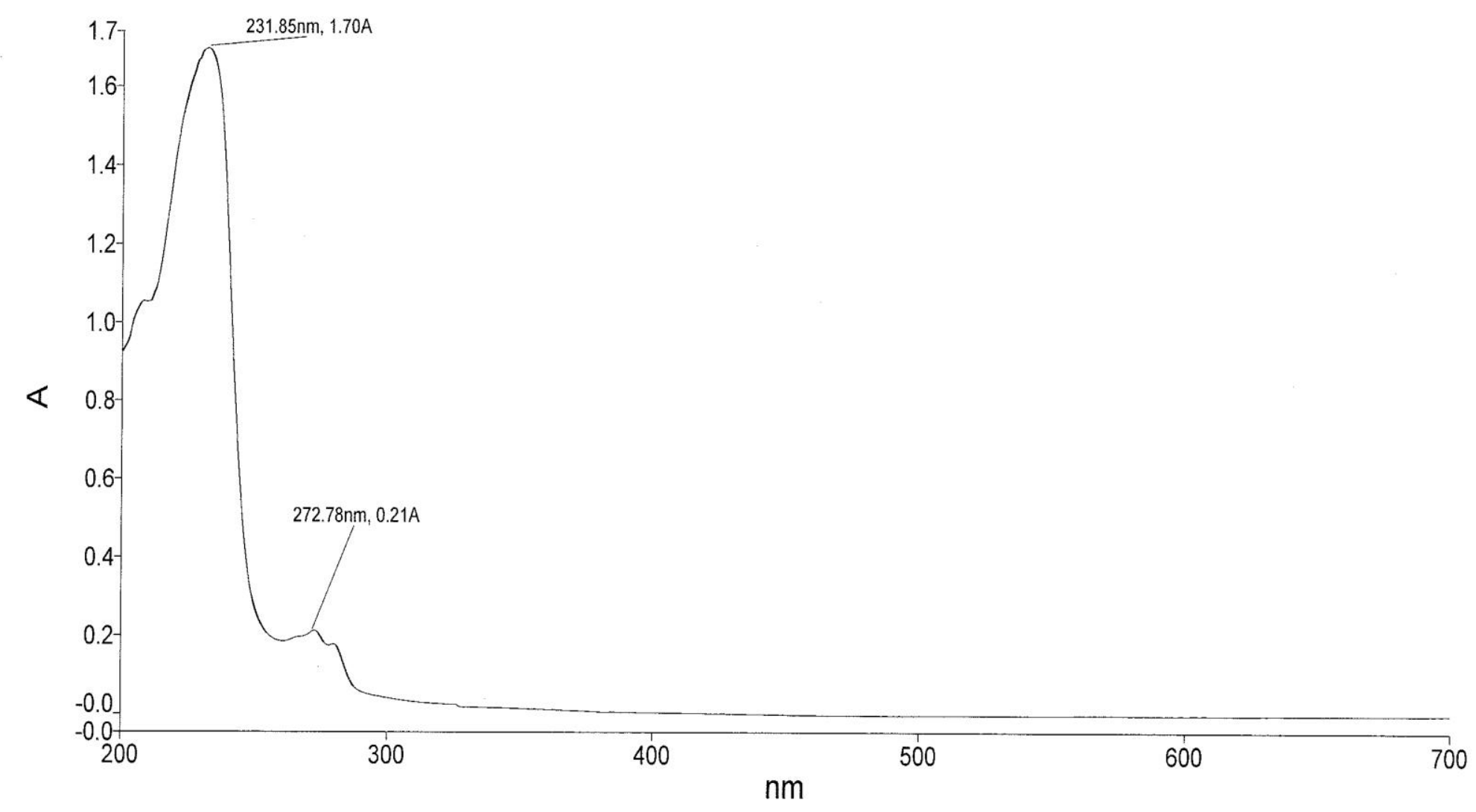


Crystallographic Data

Basimarol A (3)

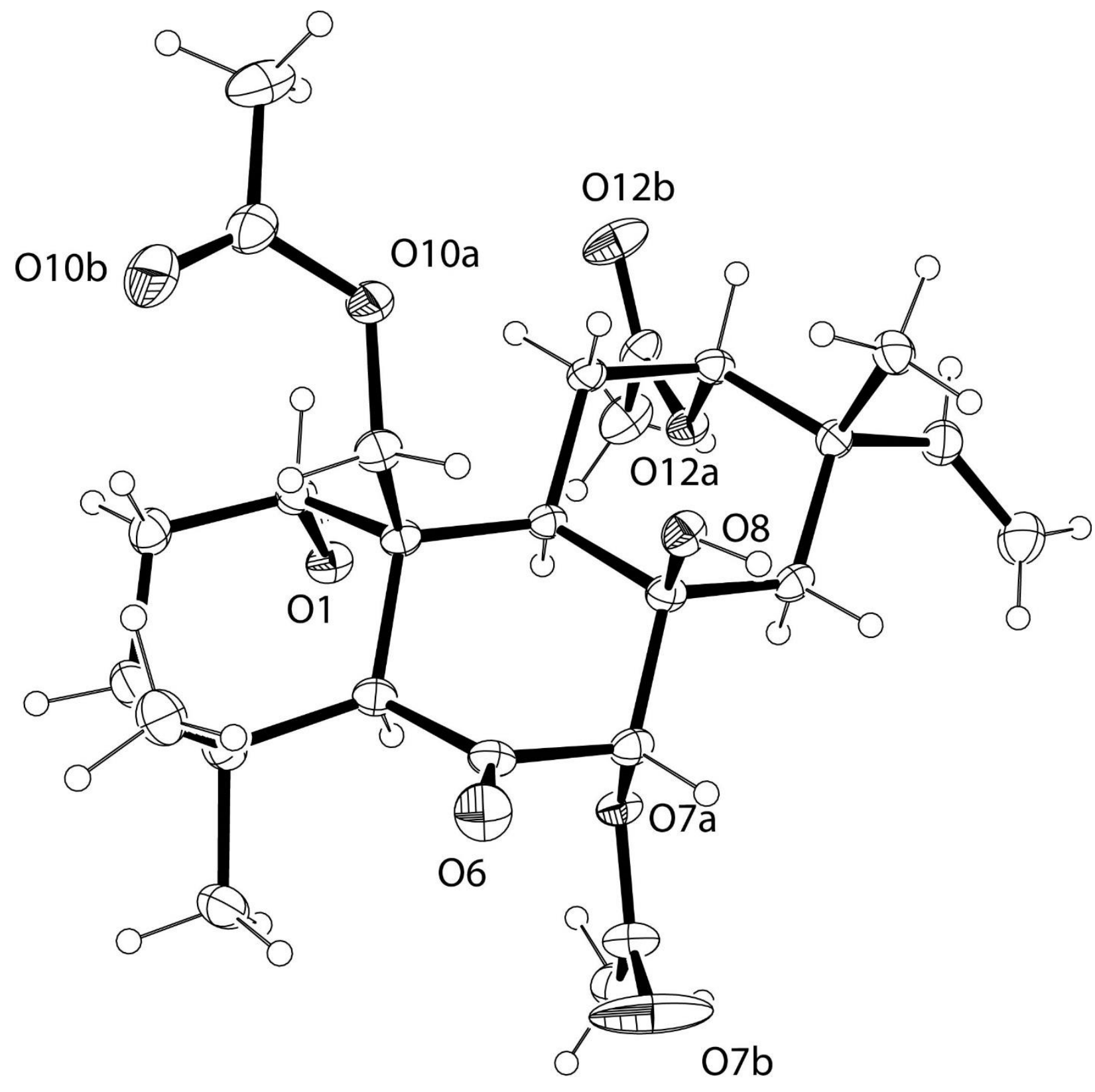



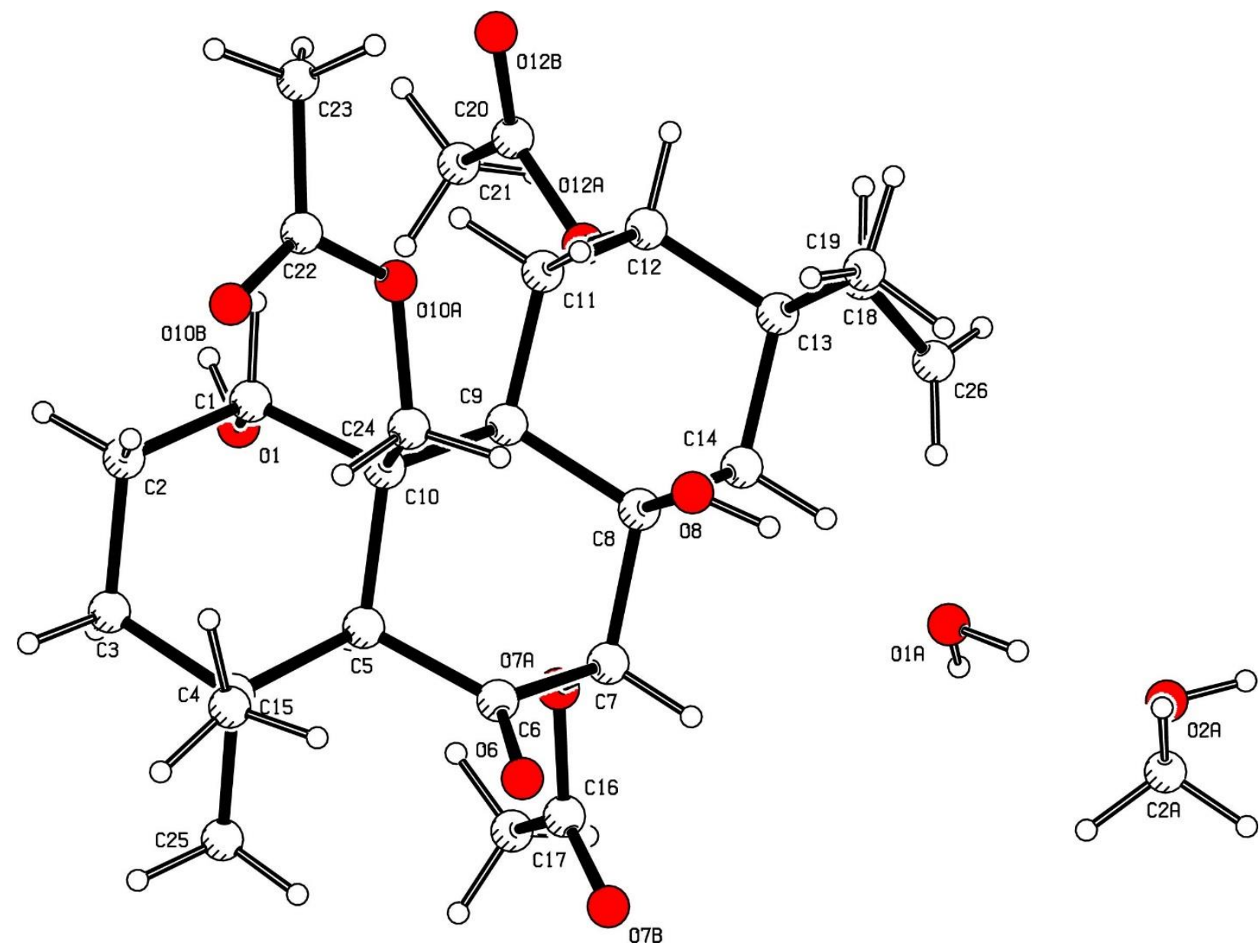
Table 1. Crystal data and structure refinement for 1722e2p14-8-3.

Identification code

Empirical formula

Formula weight

Temperature

Wavelength

Crystal system

Space group

Unit cell dimensions

Volume

$\mathbf{Z}$

Density (calculated)

Absorption coefficient

$\mathbf{F}(\mathbf{0 0 0})$

Crystal size

Theta range for data collection

Index ranges

Reflections collected

Independent reflections

Completeness to theta $=62.37^{\circ}$

Absorption correction

Max. and min. transmission

Refinement method

Data / restraints / parameters

Goodness-of-fit on $\mathbf{F}^{2}$

Final $\mathbf{R}$ indices [I $>2 \operatorname{sigma}(\mathrm{I})]$

$\mathbf{R}$ indices (all data)

Absolute structure parameter

Largest diff. peak and hole 1722e2p14-8-3

$\mathrm{C}_{26} \mathrm{H}_{38} \mathrm{O}_{9} \mathrm{CH}_{3} \mathrm{OH} . \mathrm{H}_{2} \mathrm{O}$

544.62

190(2) K

$1.54184 \AA$

Orthorhombic

$P 2122_{1}$

$a=8.3391(2) \AA \quad \alpha=9^{\circ}$.

$b=17.8877(5) \AA \quad \beta=90^{\circ}$.

$\mathrm{c}=19.2240(5) \AA \quad \gamma=90^{\circ}$.

2867.59(13) $\AA^{3}$

4

$1.261 \mathrm{Mg} / \mathrm{m}^{3}$

$0.809 \mathrm{~mm}^{-1}$

1176

$0.2 \times 0.1 \times 0.04 \mathrm{~mm}^{3}$

4.60 to $62.37^{\circ}$

$-9<=h<=9,-18<=k<=20,-22<=l<=21$

12804

$4544[R($ int $)=0.0307]$

$99.7 \%$

Semi-empirical from equivalents

1 and 0.97121

Full-matrix least-squares on $\mathbf{F}^{2}$

4544 / 0 / 352

1.050

$\mathrm{R} 1=0.0364, \mathrm{wR2}=0.0923$

$\mathrm{R} 1=\mathbf{0 . 0 3 9 6}, \mathrm{wR2}=\mathbf{0 . 0 9 5 0}$

$-0.14(16)$

0.351 and -0.188 e. $\AA^{-3}$ 
Table 2. Bond lengths $[\AA]$ and angles $\left[{ }^{\circ}\right]$ for $1722 \mathrm{e} 2 \mathrm{p} 14-8-3$.

\begin{tabular}{|c|c|}
\hline $\mathbf{C}(1)-\mathbf{O}(1)$ & $1.441(2)$ \\
\hline $\mathbf{C}(1)-\mathrm{C}(2)$ & $1.529(3)$ \\
\hline$C(1)-C(10)$ & $1.546(3)$ \\
\hline $\mathrm{C}(2)-\mathrm{C}(3)$ & $1.522(3)$ \\
\hline $\mathrm{C}(3)-\mathrm{C}(4)$ & $1.540(3)$ \\
\hline $\mathrm{C}(4)-\mathrm{C}(25)$ & $1.537(3)$ \\
\hline$C(4)-C(15)$ & $1.542(3)$ \\
\hline$C(4)-C(5)$ & $1.558(3)$ \\
\hline$C(5)-C(6)$ & $1.514(3)$ \\
\hline $\mathrm{C}(5)-\mathrm{C}(10)$ & $1.579(3)$ \\
\hline $\mathrm{C}(6)-\mathrm{O}(6)$ & $1.211(2)$ \\
\hline $\mathrm{C}(6)-\mathrm{C}(7)$ & $1.525(3)$ \\
\hline $\mathrm{C}(7)-\mathrm{O}(7 \mathrm{~A})$ & $1.460(2)$ \\
\hline$C(7)-C(8)$ & $1.538(3)$ \\
\hline $\mathrm{C}(\mathbf{8})-\mathrm{O}(\mathbf{8})$ & $1.436(2)$ \\
\hline $\mathrm{C}(8)-\mathrm{C}(14)$ & $1.530(3)$ \\
\hline $\mathbf{C}(8)-\mathbf{C}(9)$ & $1.545(3)$ \\
\hline $\mathbf{C}(9)-C(11)$ & $1.539(3)$ \\
\hline $\mathrm{C}(9)-\mathrm{C}(10)$ & $1.565(3)$ \\
\hline $\mathrm{C}(10)-\mathrm{C}(24)$ & $1.547(3)$ \\
\hline $\mathrm{C}(11)-\mathrm{C}(12)$ & $1.522(3)$ \\
\hline $\mathrm{C}(12)-\mathrm{O}(12 \mathrm{~A})$ & $1.473(2)$ \\
\hline $\mathrm{C}(12)-\mathrm{C}(13)$ & $1.529(3)$ \\
\hline $\mathrm{C}(13)-\mathrm{C}(18)$ & $1.513(3)$ \\
\hline C(13)-C(14) & $1.539(3)$ \\
\hline $\mathrm{C}(13)-\mathrm{C}(19)$ & $1.547(3)$ \\
\hline $\mathrm{C}(16)-\mathrm{O}(7 \mathrm{~B})$ & $1.183(3)$ \\
\hline $\mathrm{C}(16)-\mathrm{O}(7 \mathrm{~A})$ & $1.325(3)$ \\
\hline $\mathbf{C}(16)-C(17)$ & $1.477(3)$ \\
\hline $\mathrm{C}(18)-\mathrm{C}(26)$ & $1.310(3)$ \\
\hline $\mathrm{C}(20)-\mathrm{O}(12 \mathrm{~B})$ & $1.202(3)$ \\
\hline $\mathrm{C}(20)-\mathrm{O}(12 \mathrm{~A})$ & $1.334(3)$ \\
\hline $\mathrm{C}(20)-\mathrm{C}(21)$ & $1.493(3)$ \\
\hline $\mathrm{C}(22)-\mathrm{O}(10 \mathrm{~B})$ & $1.188(3)$ \\
\hline $\mathrm{C}(22)-\mathrm{O}(10 \mathrm{~A})$ & $1.340(3)$ \\
\hline $\mathrm{C}(22)-\mathrm{C}(23)$ & $1.492(4)$ \\
\hline
\end{tabular}




\begin{tabular}{|c|c|}
\hline$C(24)-O(10 A)$ & $1.454(3)$ \\
\hline $\mathrm{C}(2 \mathrm{~A})-\mathrm{O}(2 \mathrm{~A})$ & $1.392(4)$ \\
\hline $\mathrm{O}(1)-\mathrm{C}(1)-\mathrm{C}(2)$ & $108.84(16)$ \\
\hline $\mathrm{O}(1)-\mathrm{C}(1)-\mathrm{C}(10)$ & $108.25(15)$ \\
\hline C(2)-C(1)-C(10) & $112.57(16)$ \\
\hline$C(3)-C(2)-C(1)$ & 111.78(17) \\
\hline C(2)-C(3)-C(4) & 113.54(17) \\
\hline C(25)-C(4)-C(3) & $107.83(18)$ \\
\hline$C(25)-C(4)-C(15)$ & $107.54(18)$ \\
\hline C(3)-C(4)-C(15) & $109.67(18)$ \\
\hline$C(25)-C(4)-C(5)$ & $107.28(17)$ \\
\hline$C(3)-C(4)-C(5)$ & $107.15(16)$ \\
\hline$C(15)-C(4)-C(5)$ & 117.02(17) \\
\hline$C(6)-C(5)-C(4)$ & $116.10(16)$ \\
\hline $\mathrm{C}(6)-\mathrm{C}(5)-\mathrm{C}(10)$ & $109.75(15)$ \\
\hline$C(4)-C(5)-C(10)$ & $119.05(16)$ \\
\hline $\mathrm{O}(6)-\mathrm{C}(6)-\mathrm{C}(5)$ & $126.33(19)$ \\
\hline $\mathrm{O}(6)-\mathrm{C}(6)-\mathrm{C}(7)$ & $120.80(18)$ \\
\hline$C(5)-C(6)-C(7)$ & $112.84(16)$ \\
\hline$O(7 A)-C(7)-C(6)$ & $110.02(16)$ \\
\hline $\mathrm{O}(7 \mathrm{~A})-\mathrm{C}(7)-\mathrm{C}(8)$ & $107.80(15)$ \\
\hline $\mathrm{C}(6)-\mathrm{C}(7)-\mathrm{C}(8)$ & $108.74(15)$ \\
\hline $\mathrm{O}(8)-\mathrm{C}(8)-\mathrm{C}(14)$ & $112.65(16)$ \\
\hline $\mathbf{O}(8)-\mathrm{C}(8)-\mathrm{C}(7)$ & $104.82(14)$ \\
\hline $\mathrm{C}(14)-\mathrm{C}(8)-\mathrm{C}(7)$ & $109.79(15)$ \\
\hline $\mathbf{O}(8)-\mathrm{C}(8)-\mathrm{C}(9)$ & 108.91(15) \\
\hline $\mathrm{C}(14)-\mathrm{C}(8)-\mathrm{C}(9)$ & $109.98(15)$ \\
\hline C(7)-C(8)-C(9) & $110.60(16)$ \\
\hline $\mathrm{C}(11)-\mathrm{C}(9)-\mathrm{C}(8)$ & $108.98(15)$ \\
\hline $\mathrm{C}(11)-\mathrm{C}(9)-\mathrm{C}(10)$ & 113.91(15) \\
\hline C(8)-C(9)-C(10) & 116.14(15) \\
\hline $\mathrm{C}(1)-\mathrm{C}(10)-\mathrm{C}(24)$ & $109.41(15)$ \\
\hline $\mathbf{C}(1)-C(10)-C(9)$ & $109.90(15)$ \\
\hline $\mathbf{C}(24)-\mathrm{C}(10)-\mathrm{C}(9)$ & $112.39(15)$ \\
\hline $\mathrm{C}(1)-\mathrm{C}(10)-\mathrm{C}(5)$ & $106.06(15)$ \\
\hline$C(24)-C(10)-C(5)$ & $110.64(15)$ \\
\hline$C(9)-C(10)-C(5)$ & $108.25(14)$ \\
\hline
\end{tabular}




\begin{tabular}{|c|c|}
\hline $\mathrm{C}(12)-\mathrm{C}(11)-\mathrm{C}(9)$ & $112.44(15)$ \\
\hline $\mathrm{O}(12 \mathrm{~A})-\mathrm{C}(12)-\mathrm{C}(11)$ & $108.72(15)$ \\
\hline $\mathrm{O}(12 \mathrm{~A})-\mathrm{C}(12)-\mathrm{C}(13)$ & $107.27(15)$ \\
\hline $\mathrm{C}(11)-\mathrm{C}(12)-\mathrm{C}(13)$ & $114.04(16)$ \\
\hline $\mathrm{C}(18)-\mathrm{C}(13)-\mathrm{C}(12)$ & $109.48(16)$ \\
\hline C(18)-C(13)-C(14) & 111.15(17) \\
\hline$C(12)-C(13)-C(14)$ & $109.83(16)$ \\
\hline $\mathrm{C}(18)-\mathrm{C}(13)-\mathrm{C}(19)$ & $105.83(17)$ \\
\hline C(12)-C(13)-C(19) & $108.14(16)$ \\
\hline $\mathrm{C}(14)-\mathrm{C}(13)-\mathrm{C}(19)$ & $112.30(16)$ \\
\hline $\mathrm{C}(\mathbf{8})-\mathrm{C}(14)-\mathrm{C}(13)$ & $115.18(16)$ \\
\hline $\mathrm{O}(7 \mathrm{~B})-\mathrm{C}(16)-\mathrm{O}(7 \mathrm{~A})$ & $121.7(2)$ \\
\hline$O(7 B)-C(16)-C(17)$ & $125.0(2)$ \\
\hline$O(7 A)-C(16)-C(17)$ & $113.28(19)$ \\
\hline $\mathrm{C}(26)-\mathrm{C}(18)-\mathrm{C}(13)$ & $128.0(2)$ \\
\hline $\mathrm{O}(12 \mathrm{~B})-\mathrm{C}(20)-\mathrm{O}(12 \mathrm{~A})$ & 123.9(2) \\
\hline$O(12 B)-C(20)-C(21)$ & 124.0(2) \\
\hline $\mathrm{O}(12 \mathrm{~A})-\mathrm{C}(20)-\mathrm{C}(21)$ & $112.06(19)$ \\
\hline $\mathrm{O}(10 \mathrm{~B})-\mathrm{C}(22)-\mathrm{O}(10 \mathrm{~A})$ & $123.5(2)$ \\
\hline $\mathrm{O}(10 \mathrm{~B})-\mathrm{C}(22)-\mathrm{C}(23)$ & $125.0(2)$ \\
\hline $\mathrm{O}(10 \mathrm{~A})-\mathrm{C}(22)-\mathrm{C}(23)$ & $111.5(2)$ \\
\hline$O(10 A)-C(24)-C(10)$ & $110.38(16)$ \\
\hline $\mathbf{C}(16)-\mathrm{O}(7 \mathrm{~A})-\mathrm{C}(7)$ & $117.59(15)$ \\
\hline$C(22)-O(10 A)-C(24)$ & $119.01(17)$ \\
\hline $\mathrm{C}(20)-\mathrm{O}(12 \mathrm{~A})-\mathrm{C}(12)$ & $117.10(16)$ \\
\hline
\end{tabular}

Symmetry transformations used to generate equivalent atoms: 


\section{Biological Assays}

\section{Cytotoxicity Assays}

Sulforhodamine B (SRB) was utilised for the evaluation of the cytotoxicity against human fibroblast (NFF), melanoma (SK-MEL-28), and breast cancer (MCF7). Cells (3000 well) were seeded in triplicate 96-well plates in Roswell Park Memorial Institute (RPMI)-1640 medium containing $331 \mu \mathrm{M}$ (final) equivalent of the95:5 mixture of 4 and 8 at the top well. Then, 1 in 10 dilutions to the bottom were made, reserving last row as a no treatment negative control. Incubation was complete after 6 days at $37^{\circ} \mathrm{C}$.

MTT (3-(4,5-dimethylthiazol-2-yl)-2,5-diphenyltetrazolium bromide) was utilised for the evaluation of the cytotoxicity against Vero (African green monkey kidney) cells. Vero cells were seeded at 20,000 cells per well overnight. Various concentrations of substrate were incubated with cells $(100 \mu \mathrm{l} /$ well). At $72 \mathrm{~h}$ post incubation, MTT at 400 $\mathrm{ng} / \mathrm{ml}$ was added in SF media $(100 \mu \mathrm{l} /$ well) and incubated with cells for $1 \mathrm{~h}$ in a humidified incubator at $37^{\circ} \mathrm{C}$ and $5 \% \mathrm{CO}_{2}$. Media was removed and cells solubilized

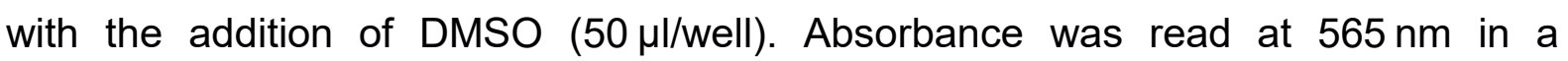
Spectramax Microplate Reader (Molecular Devices).

\section{Cells and Assays}

Vero cells were maintained in Opti-MEM media (Invitrogen) supplemented with 3\% heat-inactivated fetal bovine serum (FBS). Madin-Darby canine kidney (MDCK) cells were maintained in Dulbecco's Modified Eagle Medium (DMEM) supplemented with $10 \%$ FBS, $100 \mathrm{U} / \mathrm{mL}$ of penicillin and $100 \mu \mathrm{g} / \mathrm{mL}$ streptomycin (Gibco). C6/36 cells were grown at $28^{\circ} \mathrm{C}$ in RPMI media (Invitrogen) supplemented with $10 \%$ FBS and $25 \mathrm{mM}$ HEPES. All mammalian cell lines were incubated at $37^{\circ} \mathrm{C}$ in a humidified incubator supplemented with $5 \% \mathrm{CO}_{2}$. DENV and WNVKun stocks were propagated in C6/36 cells. Influenza viruses H1N1 (A/California/04/2009(H1N1pdm) and H3N2 (A/Switzerland/9715293/2013) were grown in MDCK cells. All viral titers were determined by serial dilution on vero or MDCK cells using an immunoplaque detection method. ${ }^{[1]}$ 


\section{Plaque-Reduction Neutralization (PRNT) Assays}

PRNT assays were performed as previously describe. [2] Briefly, confluent monolayers of MDCK cells (for influenza viruses H1N1 and H3N2) or vero cells (for flaviviruses DENV and $W N V_{\text {Kun }}$ ) were grown in 96-well flat bottom tissue culture plates (Nunc) and washed with OptiMEM prior to viral infection. Viruses were mixed at a 1:1 ratio with a titration of compounds at a final virus concentration of 2000 $\mathrm{pfu} / \mathrm{mL}$ for influenza and $1000 \mathrm{pfu} / \mathrm{ml}$ for DENV and $W N V_{\text {Kun. Viruses and }}$ compounds were incubated for $1 \mathrm{~h}$ and then transferred to cell monolayers (50 $\mu \mathrm{l} /$ well). After $1 \mathrm{~h}$ the mixture was overlayed with carboxymethyl cellulose (CMC) overlay comprising 1.5\% CMC, 2\% FCS in M199 Medium (Sigma) at $100 \mu \mathrm{l} /$ well, with the further addition of $2 \mu \mathrm{g} / \mathrm{mL}$ TPCK-Trypsin (Sigma) for the influenza viruses. Cells were then incubated for $72 \mathrm{~h}$ and fixed with ice cold $80 \%$ acetone in PBS. Plates were dried and blocked with $5 \%$ milk diluent blocking concentrate $(\mathrm{KPL})$ in PBS supplemented with $0.05 \%$ Tween 20 . Primary antibodies were added at $2 \mu \mathrm{g} / \mathrm{mL}$ (hFI6v3 for influenza, h4E11 for DENV and hE16 for WNVKun), $50 \mu l /$ well. After incubation at $37^{\circ} \mathrm{C}$ for $1 \mathrm{~h}$, plates were washed three times with PBS supplemented with $0.05 \%$ Tween 20 and then incubated with secondary antibody (IRDye800CW goat anti-human, LI-COR Biosciences, 1:2500). Plates were incubated and washed as above before drying. Plates were scanned on the Odyssey imager (LI-COR Biosciences) at $41 \mu \mathrm{M}$ resolution and plaques counted by eye with the aid of computer imaging software (Adobe Photoshop). I $\mathrm{I}_{50}$ values for PRNT were derived from a three-parameter dose response curve fit to plaque numbers obtained for compound titration performed in duplicate. 


\section{Bibliography}

[1] D. Watterson, J. Robinson, K. J. Chappell, M. S. Butler, D. J. Edwards, S. R. Fry, I. M. Bermingham, M. A. Cooper, P. R. Young, Sci. Rep. 2016, 6, 22791.

[2] Y. P. Tan, S. D. Houston, N. Modhiran, A. I. Savchenko, G. M. Boyle, P. R. Young, D. Watterson, C. M. Williams, Chem. Eur. J. 2019, 25, 5664-5667. 